Article

\title{
Experimental and Techno-Economic Study on the Use of Microalgae for Paper Industry Effluents Remediation
}

\author{
Maria I. Silva ${ }^{1}$, Ana L. Gonçalves ${ }^{1}\left(\mathbb{D}\right.$, Vítor J. P. Vilar ${ }^{2}$ and José C. M. Pires ${ }^{1, *(D)}$ \\ 1 LEPABE Laboratory for Process Engineering, Environment, Biotechnology and Energy, \\ Faculty of Engineering, University of Porto, 4200-465 Porto, Portugal; up201506660@fe.up.pt (M.I.S.); \\ algoncalves@fe.up.pt (A.L.G.) \\ 2 Laboratory of Separation and Reaction Engineering-Laboratory of Catalysis and Materials (LSRE-LCM), \\ Faculty of Engineering, University of Porto, 4200-465 Porto, Portugal; vilar@fe.up.pt \\ * Correspondence: jcpires@fe.up.pt; Tel.: +351-22-508-2262
}

Citation: Silva, M.I.; Gonçalves, A.L.; Vilar, V.J.P.; Pires, J.C.M. Experimental and Techno-Economic Study on the Use of Microalgae for Paper Industry Effluents Remediation. Sustainability 2021, 13, 1314. https://doi.org/ $10.3390 /$ su13031314

Academic Editor: Vincenzo Torretta Received: 16 December 2020

Accepted: 23 January 2021

Published: 27 January 2021

Publisher's Note: MDPI stays neutral with regard to jurisdictional claims in published maps and institutional affiliations.

Copyright: (c) 2021 by the authors. Licensee MDPI, Basel, Switzerland. This article is an open access article distributed under the terms and conditions of the Creative Commons Attribution (CC BY) license (https:/ / creativecommons.org/licenses/by/ $4.0 /)$.

\begin{abstract}
Humanity is facing some major global threats, namely lack of environmental sustainability, the energy crisis associated with the unsustainable reliance on fossil fuels, and water scarcity, which will be exacerbated with the rapid growth of urban areas. Researchers have drawn their attention to microalgae, photosynthetic microorganisms known for their environmental applications, such as wastewater remediation and lipids accumulation, to produce third-generation biofuels to solve some of these major issues. Considering this dual role, this study evaluated the potential of the microalga Chlorella vulgaris on nutrient removal from a paper industry effluent and bioenergy production. Firstly, experiments were performed to assess the potential of this microalga to: (i) successfully grow in different concentrations of a paper industry effluent (20\% to $100 \%$ ); and (ii) treat the industrial effluent, reducing phosphorus concentrations to values below the accepted legal limits. Then, a techno-economic assessment was performed to study the viability of a C. vulgaris biorefinery targeting the remediation of a paper industry effluent and bioenergy production. The results have shown that $C$. vulgaris was able to successfully grow and treat the paper industry effluent. Under these conditions, average biomass productivities determined for this microalga ranged between $15.5 \pm 0.5$ and $26 \pm 1 \mathrm{mg}$ dry weight (DW) $\mathrm{L}^{-1} \mathrm{~d}^{-1}$, with maximum biomass concentrations reaching values between $337 \pm 9$ and $495 \pm 25 \mathrm{mg} \mathrm{DW} \mathrm{L}^{-1} \mathrm{~d}^{-1}$. Moreover, final phosphorus concentrations ranged between $0.12 \pm 0.01$ and $0.5 \pm 0.3 \mathrm{mg} \mathrm{P} \mathrm{L}^{-1}$, values below the legal limits imposed by the Portuguese Environment Agency on the paper industry. Regarding the proposal of a microalgal biorefinery for the bioremediation of paper industry effluents with bioenergy production, the techno-economic study demonstrated that six of the seven studied scenarios resulted in an economically-viable infrastructure. The highest net present value (15.4 million euros) and lowest discounted payback period (13 years) were determined for Scenario 3, which assumed a photosynthetic efficiency of 3\%, a lipids extraction efficiency of $75 \%$, and an anaerobic digestion efficiency of $45 \%$. Therefore, it was possible to conclude that besides being economically viable, the proposed biorefinery presents several environmental benefits: (i) the remediation of an industrial effluent; (ii) $\mathrm{CO}_{2}$ uptake for microalgal growth, which contributes to a reduction in greenhouse gases emissions; (iii) production of clean and renewable energy; (iv) soil regeneration; and (v) promotion of a circular economy.
\end{abstract}

Keywords: bioenergy production; biofuels; Chlorella vulgaris; microalgal biorefinery; nutrient removal; paper industry effluents; sustainability; techno-economic assessment

\section{Introduction}

The booming world population, economic growth, and improved living standards are leading to an increase in the global demand for energy and natural and non-natural resources, putting huge pressure on the environment [1,2]. Most of the anthropogenic activities required to satisfy these increasing demands rely on the burning of fossil fuels, 
which constitutes one of the largest emission sources of greenhouse gases (GHGs), thus having a major impact on global warming [3,4]. Moreover, fossil fuel-related sectors and other anthropogenic activities, such as agriculture, industrialization, and urbanization contribute to freshwater scarcity in terms of quantity and quality. Therefore, it is of prime and utmost importance to redesign and create new systems, develop innovative technologies, and investigate new sources, especially in the energy and transportation sectors, to reduce the environmental impacts caused by human-related activities $[5,6]$. Only then, a transition from a fossil-based linear economy to a circular-based (bio)economy will be possible, and this transition is one of the main requirements to achieve global sustainability $[7,8]$.

Many alternative solutions are being studied, and some have already been implemented. Regarding renewable energy sources, biofuels (e.g., bioalcohols, biodiesel, and biogas) have been studied and developed worldwide, as they seem to be good candidates for a long-term replacement of fossil fuels $[3,9,10]$. These fuel sources have characteristics very similar to those of fossil fuels and, yet, have a better environmental performance [11]. Biodiesel based on vegetable oil crops (e.g., rapeseed, soybean, palm, and peanut) presents many benefits compared to fossil fuels. However, it also presents a lot of negative impacts, such as the use of pesticides and fertilizers, and the requirement of great areas that compete with resources needed for food security (e.g., arable land and freshwater) [1,12-14].

In the last years, microalgae have drawn the attention of researchers, due to their ability to accumulate lipids that can be further converted into biodiesel. Moreover, the use of microalgae as a source for biofuels production presents several advantages: (i) higher productivities than other crops; (ii) higher lipid contents ( $30 \%)$; (iii) reduced land requirements; (iv) no competition with resources needed for food supply; (v) possibility to grow in wastewaters and promote their treatment; (vi) ability for $\mathrm{CO}_{2}$ sequestration and oxygen release (when growing autotrophically); and (vii) ability to accumulate other products of commercial value [3,12,15-18]. Nevertheless, there are a few bottlenecks when scaling up microalgal production. To overcome these obstacles and enhance the economic viability of this process, it is necessary to fully exploit the potential of these microorganisms, which leads to a biorefinery approach $[1,19]$. These new infrastructures have a similar concept to the one from traditional oil refineries, the main differences being (i) the raw materials used in each one (biomass or crude oil) and (ii) the applied technology. Considering the relevance of microalgal biorefineries in the sustainability of microalgal-based processes, especially for environmental applications such as wastewater treatment, this study aimed to design and propose a microalgal production system for nutrient removal from a paper industry effluent and bioenergy production. To determine the potential of microalgae in the remediation of these effluents, an experimental study evaluating the influence of different effluent loads on the growth of the microalga Chlorella vulgaris was promoted. Then, an economic and sustainability assessment was performed to study the viability of a microalgal biorefinery for the bioremediation of industrial effluents and biomass valorization (for energetic purposes, mainly).

The development of effective treatment processes for paper industry effluents is critical. The paper industry represents an important economic sector in Portugal that requires and disposes large amounts of water, which typically presents high phosphorus concentrations (one of the major contributors to the eutrophication phenomenon). Moreover, the development of a biorefinery from the treatment process constitutes an opportunity for value generation, contributing to the development of closed-loop business models and the deployment of a circular economy.

\section{Materials and Methods}

2.1. Paper Industry Effluent Remediation Using Microalgae: Experimental Work

2.1.1. Microalgal Strain and Inoculum Preparation

The strain used in this study, C. vulgaris CCAP 211/11B, was provided by the Culture Collection of Algae and Protozoa (CCAP, Scotland, UK). Stock solutions were prepared in 
100-mL Erlenmeyer flasks, with working volume of $50 \mathrm{~mL}$, using a modified version of the OECD (Organization for Economic Cooperation and Development) test medium [20], with the following composition (per liter): $250 \mathrm{mg} \mathrm{NaNO}_{3} ; 12 \mathrm{mg} \mathrm{MgCl}_{2} \cdot 6 \mathrm{H}_{2} \mathrm{O}$; $18 \mathrm{mg} \mathrm{CaCl} 2 \cdot 2 \mathrm{H}_{2} \mathrm{O} ; 15 \mathrm{mg} \mathrm{MgSO}_{4} \cdot 7 \mathrm{H}_{2} \mathrm{O} ; 45 \mathrm{mg} \mathrm{K \textrm {H } _ { 2 }} \mathrm{PO}_{4} ; 0.08 \mathrm{mg} \mathrm{FeCl} \cdot 6 \mathrm{H}_{2} \mathrm{O} ; 0.1 \mathrm{mg}$ $\mathrm{Na}_{2}$ EDTA $\cdot 2 \mathrm{H}_{2} \mathrm{O} ; 0.185 \mathrm{mg} \mathrm{H} \mathrm{BO}_{3} ; 0.415 \mathrm{mg} \mathrm{MnCl} \cdot 4 \mathrm{H}_{2} \mathrm{O} ; 3 \mu \mathrm{g} \mathrm{ZnCl} ; 1.5 \mu \mathrm{g} \mathrm{CoCl} \cdot 6 \mathrm{H}_{2} \mathrm{O}$; $0.01 \mu \mathrm{g} \mathrm{CuCl} 2 \cdot 2 \mathrm{H}_{2} \mathrm{O} ; 7 \mu \mathrm{g} \mathrm{Na} \mathrm{MoO}_{4} \cdot 2 \mathrm{H}_{2} \mathrm{O}$; and $50 \mathrm{mg} \mathrm{NaHCO}$. Erlenmeyer flasks were maintained in a thermostatic cabinet (Lovibond ${ }^{\circledR}$, Amesbury, UK) at constant temperature $\left(25^{\circ} \mathrm{C}\right)$ and continuous light supply of approximately $6.50 \mu \mathrm{mol} \cdot \mathrm{m}^{-2} \cdot \mathrm{s}^{-1}$. Agitation was promoted through a Unimax 1010 orbital shaker (Heidolph, Schwabach, Germany), set at $100 \mathrm{rpm}$ (rotations per minute).

\subsubsection{Paper Industry Effluent Characterization}

The effluent used as culture medium was obtained from a Portuguese paper company and collected after the secondary treatment step. Considering the sampling site, the effluent was characterized in terms of nitrogen $(\mathrm{N})$, in the form of nitrate, phosphorus $(\mathrm{P})$, in the form of phosphate, and chemical oxygen demand (COD). The methodology adopted for the determination of each of these parameters was [21,22]: (i) the United States Environmental Protection Agency (USEPA)-approved brucine colorimetric method for nitrate-nitrogen determination; (ii) the Spectroquant phosphate kit test (Merck, Kenilworth, Germany) for phosphate-phosphorus determination; and (iii) $5220 \mathrm{C}$ closed reflux titrimetric method from standard methods for COD determination. Total phosphorus was also determined for this effluent, but the variation in phosphate-phosphorus and total phosphorus concentrations was almost negligible. For this reason, phosphorus concentration throughout the experiments was determined in the form of phosphate-phosphorus. The results from the effluent characterization demonstrated that the paper industry effluent presented the following composition: (i) $3.6 \pm 0.6 \mathrm{mg} \mathrm{N} \mathrm{L}^{-1}$ for nitrate-nitrogen, (ii) $3.72 \pm 0.07 \mathrm{mg} \mathrm{P} \mathrm{L}^{-1}$ for phosphate-phosphorus, and (iii) $266 \pm 50 \mathrm{mg} \mathrm{O}_{2} \mathrm{~L}^{-1}$ for COD. Considering these data, it was verified that the target effluent presented a low nitrogen concentration, which may be limiting for biomass growth (N:P molar ratio determined for this effluent was about 2:1). According to Larsdotter, adequate N:P molar ratios for microalgal growth should be between 5:1 and 30:1 [23]. Therefore, to ensure an adequate nutrient supply to support C. vulgaris growth, the collected paper industry effluent was supplemented with an external nitrogen source, $\mathrm{NaNO}_{3}$, trying to obtain a $\mathrm{N}: \mathrm{P}$ molar ratio of $\approx 9: 1$.

\subsubsection{Experimental Setup}

Experiments regarding microalgal growth in the paper industry effluent were performed in batch mode, using 1000-mL borosilicate bottles as a cultivation system. To offset possible toxic effects of the paper industry effluent on microalgal growth, as well as light limitation due to the effluent color, different effluent concentrations were evaluated: $20 \%, 40 \%, 60 \%, 80 \%$, and 100\%. These concentrations were prepared by diluting the nitrogen-supplemented effluent with distilled water. In addition to these conditions, microalgal growth was promoted using the modified OECD test medium as the culture medium (positive control), and the raw effluent (100\%) supplemented with nitrogen without microalgae was submitted to the same culturing conditions (negative control). The different effluent compositions and the positive control were inoculated with $40 \mathrm{~mL}$ of a previously centrifuged $C$. vulgaris inoculum, giving an initial biomass concentration of approximately $120 \mathrm{mg} \mathrm{DW} \mathrm{L}^{-1}$. Except for the positive and negative controls, all the experiments were performed in duplicates. After inoculation, the cultures were allowed to grow for $14 \mathrm{~d}$ under continuous light supply provided by light-emitting diode (LED) lamps placed in parallel with the bottles, with photosynthetically-active radiation (PAR) of $202.9 \mu \mathrm{mol} \mathrm{m}^{-2} \mathrm{~s}^{-1}$. The $\mathrm{CO}_{2}$ necessary for microalgal photosynthesis was supplied to the cultures through the continuous injection of atmospheric air, previously filtered by $0.22-\mu \mathrm{m}$ cellulose acetate membrane filters, at a flow rate of $1.5 \mathrm{~L} \mathrm{~min}^{-1}$, using AP-180 air pumps (Trixie, Flensburg, Germany). Air injection was also performed to promote the 
cultures' mixing and avoid microalgal sedimentation. To keep the adequate temperature for microalgal growth in the coldest days, a 265-W heating tape (J.P. Selecta, Barcelona, Spain) was placed in the experimental facility. Figure 1 presents a picture of the experimental setup.

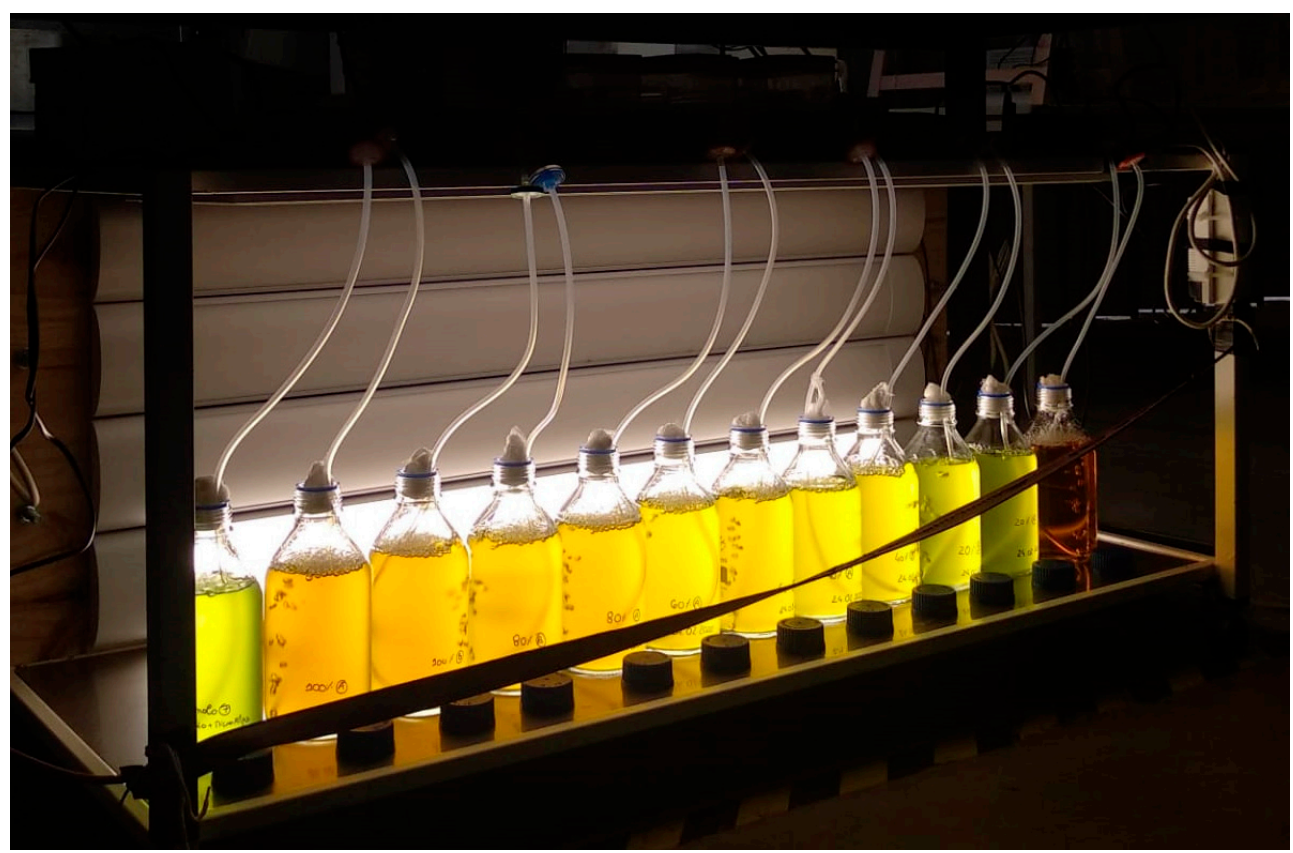

Figure 1. Experimental facility used for microalgal growth.

\subsubsection{Microalgal Growth Monitoring and Determination of Growth Parameters}

Operational parameters, such as $\mathrm{pH}$ and temperature, were daily monitored using a single channel multi-parameter analyzer (C6010, Consort, Turnhout, Belgium). Microalgal growth was also analyzed daily, by measuring the optical density at $680 \mathrm{~nm}, \mathrm{OD}_{680}$, using a GENESYS 10 UV spectrophotometer (Thermo Scientific, Waltham, MA, USA). Biomass concentration was obtained through a previously determined calibration curve that establishes the relation between $\mathrm{OD}_{680}, \mathrm{y}$, and the cell dry weight, $\mathrm{x}$, presented in Equation (1):

$$
y=(0.0023 \pm 0.0002) x-(0.123 \pm 0.008) ;\left(R^{2}=0.9758\right)
$$

With biomass concentration values, the specific growth rate $\left(\mu, \mathrm{d}^{-1}\right)$, maximum biomass concentration $\left(\mathrm{X}_{\max }, \mathrm{mg} \mathrm{DW} \mathrm{L}^{-1}\right)$, and biomass productivities $\left(\mathrm{P}_{\mathrm{X}}, \mathrm{mg} \mathrm{DW} \mathrm{L}^{-1}\right.$ $\mathrm{d}^{-1}$ ) were determined. Specific growth rates were obtained for each culture using a pseudofirst-order kinetic model (Equation (2)). With the graphical representation of Ln (X) versus time $(t, d)$, it was possible to define the exponential growth phase and determine the specific growth rate for each tested condition:

$$
\frac{\mathrm{dX}}{\mathrm{dt}}=\mu X \Leftrightarrow \ln \frac{\mathrm{X}_{1}}{\mathrm{X}_{0}}=\mu\left(\mathrm{t}_{1}-\mathrm{t}_{0}\right)
$$

where $X_{1}$ and $X_{0}$ are the biomass concentrations $\left(\mathrm{mg} \mathrm{DW} \mathrm{L}^{-1}\right)$ at final time $t_{1}(\mathrm{~d})$ and initial time $\left(t_{0}, d\right)$ of the exponential phase of microalgal growth curves, respectively. Biomass productivities were calculated for each pair of consecutive experimental points $\left(X_{z}\right.$ and $\mathrm{X}_{\mathrm{z}+1}$ ), according to Equation (3):

$$
P_{X}=\frac{X_{z+1}-X_{z}}{t_{z+1}-t_{z}}
$$


With the obtained results, the maximum biomass productivity $\left(\mathrm{P}_{\mathrm{X}, \max }\right)$ was determined, which corresponds to the highest value from the $P_{X}$ set of values. On the other hand, average biomass productivity $\left(\mathrm{P}_{\mathrm{X}, \mathrm{avg}}\right)$ was obtained from the ratio between the biomass produced during the assay and the elapsed experimental time, as defined in Equation (4):

$$
P_{X, a v g}=\frac{X_{f}-X_{i}}{t_{f}-t_{i}}
$$

where $X_{f}$ and $X_{i}$ are the biomass concentrations $\left(m g\right.$ DW L $\left.{ }^{-1}\right)$ in the final $\left(t_{f}\right)$ and initial $\left(t_{i}\right)$ instants of the cultivation period, respectively.

\subsubsection{Phosphorus Concentration Evaluation and Determination of Nutrients Removal Kinetics}

For phosphorus concentration analyses, 20-mL samples of each culture were collected on days $0,1,2,3,4,7,9,11$, and 14 . Then, the samples were centrifuged at rotational speed of $4000 \mathrm{rpm}$, for $10 \mathrm{~min}$, in an Eppendorf 5819 R centrifuge (Eppendorf, Hamburg, Germany). As previously mentioned, phosphorus was analyzed in terms of phosphatephosphorus using the Spectroquant phosphate kit test. To evaluate phosphorus removal under the studied conditions, removal efficiencies (RE (\%)), mass removal per unit of volume (MR, mg P L $\left.{ }^{-1}\right)$, and average removal rates $\left(\mathrm{RR}, \mathrm{mg} \mathrm{P} \mathrm{L}^{-1} \mathrm{~d}^{-1}\right.$ ) were calculated according to Equations (5)-(7), respectively:

$$
\begin{gathered}
R E(\%)=\frac{S_{i}-S_{f}}{S_{i}} \times 100 \\
M R=S_{i}-S_{f} \\
R R=\frac{S_{i}-S_{P}<0.5}{t_{P}<0.5-t_{i}}
\end{gathered}
$$

where $S_{i}$ and $S_{f}$ represent the phosphorus concentrations $\left(\mathrm{mg} \mathrm{P} \mathrm{L}^{-1}\right)$ at the initial $\left(t_{i}\right)$ and final $\left(t_{f}\right)$ instants of the cultivation period, respectively, and $\mathrm{S}_{\mathrm{P}<0.5}$ corresponds to the phosphorus concentration $\left(\mathrm{mg} \mathrm{P} \mathrm{L}^{-1}\right)$ at the instant at which phosphorus concentration reached the most demanding limit for phosphorus discharge defined by Portuguese Environment Agency (APA) in the environmental permit of the paper industry company $\left(0.5 \mathrm{mg} \mathrm{P} \mathrm{L}^{-1}\right)$. Moreover, with the values of average biomass productivity and average removal rate, both determined for the time interval at which phosphorus concentration reached $0.5 \mathrm{mg} \mathrm{P} \mathrm{L}^{-1}$, specific biomass yields $\left(\mathrm{Y}_{\mathrm{X} / \mathrm{P}}, \mathrm{g} \mathrm{DW}^{-1} \mathrm{P}\right)$ were calculated according to Equation (8):

$$
\mathrm{Y}_{\mathrm{X} / \mathrm{P}}=\frac{\mathrm{P}_{\mathrm{X}, \mathrm{P}<0.5}}{\mathrm{RR}}
$$

2.2. Microalgal-Based Biorefinery for Paper Industry Effluent Remediation: Techno-Economic and Sustainability Assessment

The major aims of the proposed C. vulgaris biorefinery are (i) to promote the treatment of an effluent resulting from the paper industry using the microalga C. vulgaris and (ii) to produce lipids and biogas from the resulting biomass. To design the production plant and study the viability and sustainability of this project, a techno-economic assessment (TEA) was performed. This TEA framework is structured according to the following steps: (i) infrastructure location; (ii) process flowsheet description; (iii) scenarios description; (iv) mass and energy balances; (v) economic assessment and sensitivity analysis; and (vi) sustainability assessment.

\subsubsection{Microalgal-Based Biorefinery Location}

When growing autotrophically, microalgal growth depends on (i) nutritional factors, such as inorganic carbon source (e.g., $\mathrm{CO}_{2}$ ), inorganic salts, and nutrients, like nitrogen and phosphorus; and (ii) environmental factors, such as light intensity, temperature, and 
environment $\mathrm{pH}$. This study proposes the cultivation of microalgae in high rate ponds (HRPs). Biomass productivities in open reactors are much more dependent on environmental factors [24]. Therefore, the plant location must be strategically chosen to optimize microalgal production and target products' accumulation. The selection should consider: (i) the weather conditions; (ii) the availability of a suitable culture medium (with all the nutrients and inorganic salts required for microalgal growth); and (iii) the existence of enough land to build the microalgal production unit [25]. Considering the above referred aspects, the proposed location for constructing this infrastructure was Setúbal, a Portuguese municipality that lies within the Lisbon metropolitan area. According to data collected from the Photovoltaic Geographical Information System (PVGIS, European Commission), average horizontal solar irradiation in this area is approximately $4.98 \mathrm{kWh} \mathrm{m}^{-2} \mathrm{~d}^{-1}$ and the average annual temperature is $16.8^{\circ} \mathrm{C}$. Regarding the risk of evaporation losses, Rodrigues [26] estimated evaporation rates in different reservoirs in southern Portugal. With the values obtained for the three reservoirs nearest to the proposed construction area, a weighted average was done, leading to an annual average evaporation rate of $0.075 \mathrm{~m} \mathrm{month}^{-1}$.

In addition to the appropriate weather and light availability conditions, the plant site chosen has other advantages: (i) the presence of an agro-industrial company with a biodiesel production plant from oilseeds and to whom biofertilizers can be sold (located at less than $50 \mathrm{~km}$ from the biorefinery); (ii) the presence of a paper company that will supply the culture medium and $\mathrm{CO}_{2}$ for microalgal growth and the sludge for anaerobic treatment (located at less than $5 \mathrm{~km}$ from the facility); (iii) proximity to water for the discharge of the treated effluent and, if necessary, to be used as an alternative culture medium (brackish water); and (iv) flat topography, which avoids the necessity for land preparation for the biorefinery construction.

\subsubsection{Process Flow Diagram}

Regarding suspended cultivation systems, they can be open or closed reactors. Despite all the drawbacks of growing microalgae in open reactors, these systems are less expensive than closed ones, are more suitable for large-scale production of microalgal biomass, and can achieve promising biomass productivities, when the selected strain is robust, and the environmental conditions are adequate for their growth $[27,28]$. Considering these advantages, open systems were proposed in this project. Figure 2 shows the process flow diagram of the proposed biorefinery plant.

To ensure an adequate microalgal growth, it is necessary to supply the cultures with the essential nutrients for their growth. Nitrogen and phosphorus are available in the culture medium that enters the HRP through $\mathrm{S}_{01}$ stream. This medium is a mixture of the effluent resulting from the paper company $\left(\mathrm{S}_{\mathrm{PE}}\right)$ with the plant recycle effluent $\left(\mathrm{S}_{\mathrm{WR}}\right)$. Carbon is supplied to the culture through the injection of flue gases resulting from: (i) the biomass plant of the paper company; and (ii) the combined heat and power (CHP) units from the proposed biorefinery and the paper company, where generators burn biogas to produce, simultaneously, electricity and heat. The carbon is assumed to be supplied as $100 \% \mathrm{CO}_{2}$ and to be free from any impurity that might negatively impact microalgal growth (e.g., sulfur or nitrogen oxides) [28]. Biomass harvesting is done following a two-stage approach [29,30]: (i) first, a thickening step, flocculation, is applied to make biomass settle faster in the clarifier and to separate it from the culture medium $\left(\mathrm{S}_{03}\right)$ more easily; and (ii) a dewatering step will be promoted, where biomass is centrifuged to end up with a concentration of approximately $20 \%(w / w)\left(\mathrm{S}_{04}\right)$. From all the cell disruption and products' extraction techniques, pulsed electric field (PEF) was the selected one. This technique presents several advantages: (i) avoids the use of chemicals; (ii) can be easily scaled up; (iii) does not require a dewatering process; (iv) has a very short treatment time; and (v) has low energetic requirements and operational costs [31-34]. The lipids extracted $\left(\mathrm{S}_{05}\right)$ can then be sold to the above mentioned agro-industrial company that will transform microalgal lipids into biodiesel through transesterification. The biomass resulting from the lipids' extraction step is then sent to an anaerobic digester $(\mathrm{AD})$ to be stabilized $\left(\mathrm{S}_{06}\right)$. Part of the sludge 
from the paper industry wastewater treatment plant (WWTP), $\mathrm{S}_{09}$, is also sent to the AD. As a result of this process, biogas $\left(\mathrm{S}_{07}\right)$ and biofertilizers $\left(\mathrm{S}_{08}\right)$ are produced. The biogas is burned to produce electricity and heat that can be further used to fulfill the biorefinery energy and heating needs.

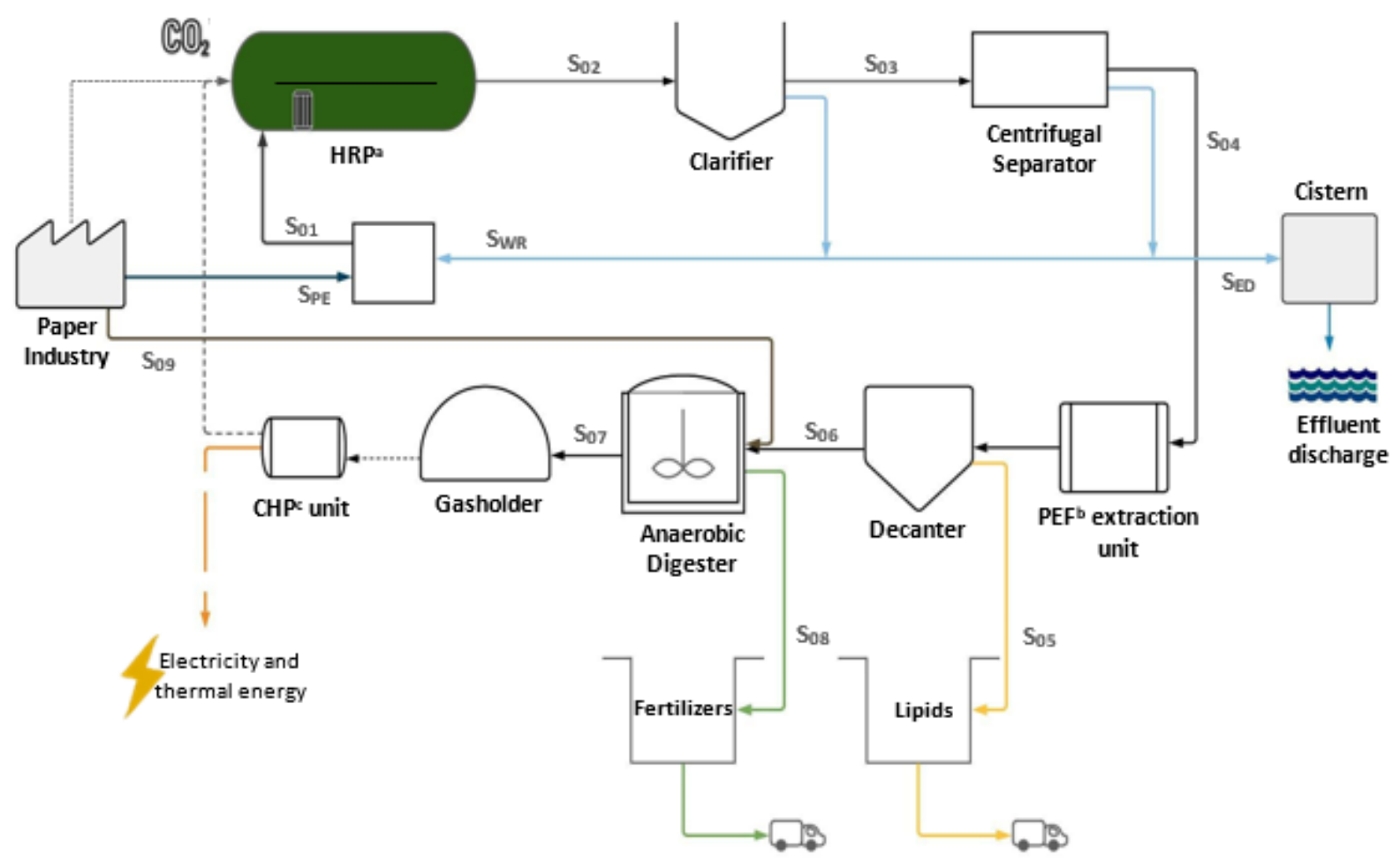

Figure 2. Process flow diagram; ${ }^{\mathrm{a}} \mathrm{HRP}$ - high rate pond; ${ }^{\mathrm{b}} \mathrm{PEF}$ - pulsed electric field; ${ }^{\mathrm{c}} \mathrm{CHP}$ - combined heat and power (cogeneration) unit.

\subsubsection{Scenarios Description}

Seven scenarios were considered in this study, being characterized according to three important parameters for the biorefinery performance (Table 1). Scenario 1 (defined as the base scenario) is characterized by a photosynthetic efficiency (PE) of $2 \%$, which corresponds to a biomass productivity of $15.7 \mathrm{~g} \mathrm{~m}^{-2} \mathrm{~d}^{-1}$, a lipid extraction efficiency of $75 \%$, and an anaerobic digestion efficiency of $45 \%$. Scenarios 2 and 3 are different from Scenario 1 concerning PE in order to evaluate the influence of this parameter on the biorefinery viability. In Scenarios 2 and 3, PE was considered 1\% and 3\%, respectively. According to Carvalho et al. [35], in outdoor reactors, the PE values rarely exceed 6\%. Other authors compared different outdoor reactors and determined that the highest PE obtained for HRPs was $1.5 \%$ [36]. These values are typically low, due to different losses caused by reflection, photoinhibition, photon absorption, light saturation, among others [37]. Scenarios 4 and 5 are different from the base scenario regarding the efficiency of lipids extraction by the PEF unit. Lipids extraction efficiencies of $60 \%$ and $90 \%$ were defined in Scenarios 4 and 5 , respectively. Numerous studies have already presented this range of values (60-90\%) for PEF extraction efficiency [38,39]. To evaluate the impact of the anaerobic digestion efficiency on the plant performance, this parameter was defined as 30\% and $60 \%$ in Scenarios 6 and 7 , respectively. This range of values for anaerobic digestion efficiency has already been reported in the literature [40]. 
Table 1. Characterization of the seven scenarios (Sc) evaluated in this study.

\begin{tabular}{cccccccc}
\hline Parameters & Sc $\mathbf{1}$ & Sc $\mathbf{2}$ & Sc 3 & Sc 4 & Sc 5 & Sc 6 & Sc 7 \\
\hline Photosynthetic efficiency (\%) & 2 & 1 & 3 & 2 & 2 & 2 & 2 \\
Biomass productivity ( $\left.\mathrm{g} \mathrm{m}^{-2} \mathrm{~d}^{-1}\right)$ & 15.7 & 7.80 & 23.5 & 15.7 & 15.7 & 15.7 & 15.7 \\
Lipids extraction efficiency (\%) & 75 & 75 & 75 & 60 & 90 & 75 & 75 \\
Anaerobic digestion efficiency (\%) & 45 & 45 & 45 & 45 & 45 & 30 & 60 \\
\hline
\end{tabular}

\subsubsection{Mass Balance}

All the streams involved in the production of microalgal biomass and by-products are presented in Figure 2. The overall process can be divided into four major steps: (i) microalgal growth; (ii) biomass harvesting; (iii) cell disruption and lipids extraction; and (iv) anaerobic digestion and cogeneration.

The first step of the process, microalgal cultivation, was done in 25 equal HRPs with $0.3 \mathrm{~m}$ height, $60 \mathrm{~m}$ large, and $690 \mathrm{~m}$ long, similar to those described by Lundquist et al. [41]. Therefore, the plant presents a total area of 100 ha and a total volume of $300,000 \mathrm{~m}^{3}$ for microalgal growth. Average biomass productivities estimated for these systems in each scenario are presented in Table 1 . This parameter was calculated considering the average horizontal solar irradiation in the Setúbal area, microalgal energetic value, and the PE for each scenario (1\% to 3\%). Microalgal energetic value was calculated assuming a lipid content of $25 \%(w / w)$, according to Chen et al. [42] and Dong et al. [43], and the remaining $75 \%(w / w)$ was assumed to correspond to carbohydrates and protein contents. Lipids energetic value was considered to be $37.5 \mathrm{MJ} \mathrm{kg}^{-1}$ and carbohydrates and proteins energetic value $18 \mathrm{MJ} \mathrm{kg}^{-1}$ [44]. The output stream $\left(\mathrm{S}_{02}\right)$ was determined assuming the $\mathrm{HRP}$ as a continuous stirred-tank reactor and considering $0.5 \mathrm{~g} \mathrm{~L}^{-1}$ as a typical value for biomass concentration in open reactors [45]. Concerning the input stream $\left(\mathrm{S}_{01}\right)$, it was first estimated considering the output stream $\left(\mathrm{S}_{02}\right)$ plus the evaporation flow rate $\left(2500 \mathrm{~m}^{3} \mathrm{~d}^{-1}\right)$. Then, taking into account the annual average biomass productivities and the assumed molecular formula for microalgal biomass $\left(\mathrm{CH}_{1.70} \mathrm{~N}_{0.10} \mathrm{P}_{0.0004} \mathrm{~S}_{0.0009}\right)$, the nutrient removal rates were determined [46,47]. In a second step, an optimization process was done to determine the optimum volumes of wastewater from the paper industry $\left(\mathrm{S}_{\mathrm{PE}}\right)$ and recycling water $\left(\mathrm{S}_{\mathrm{WR}}\right)$, that is, the volumes that will allow inlet nutrient concentrations as close as possible to the minimum concentrations required for microalgal growth in the input stream $\left(\mathrm{S}_{01}\right)$.

Regarding biomass harvesting, thickening and dewatering steps were considered. The thickening step consisted of adding sodium hydroxide $(\mathrm{NaOH})$ to increase the $\mathrm{pH}$ and induce autoflocculation, which leads to the formation of large flocs that can be easily separated from the medium by gravity sedimentation [28]. To induce the flocculation of $1 \mathrm{~g}$ of microalgal biomass at a $\mathrm{pH}$ of 10.8 , it was assumed that $9 \mathrm{mg}$ of $\mathrm{NaOH}$ were required, which accounts for a concentration factor of 4 [48]. In the dewatering step, centrifugation was proposed, leading to a concentration factor of 100. Centrifugation is, indeed, the most expensive harvesting method, but it is also one of the most suitable for large-scale processing. The overall harvesting efficiency was considered to be $95 \%$, as reported by several authors in the literature $[49,50]$.

Lipid extraction flow rate $\left(\mathrm{S}_{05}\right)$ and the anaerobic digestion input stream $\left(\mathrm{S}_{06}\right)$ were determined taking into account the flow rate that enters in the PEF unit $\left(\mathrm{S}_{04}\right)$, the technique efficiency (60-90\%, depending on the scenario) and microalgal contents in lipids (25\% $(w / w))$.

During the anaerobic digestion stage of the biorefinery plant, microorganisms break down organic matter, converting it into methane and carbon dioxide in the absence of oxygen. Nutrient removal rates were estimated considering the input flow, as well as microalgal elemental composition after lipids extraction $\left(\mathrm{CH}_{1.70} \mathrm{~N}_{0.125} \mathrm{P}_{0.005} \mathrm{~S}_{0.001}\right)$ and the digestion efficiency (30-60\%, depending on the scenario). With those values and the biogas composition, assumed to be $60 \%$ of $\mathrm{CH}_{4}$ and $40 \%$ of $\mathrm{CO}_{2}$ (as reported in several studies), the resulting biogas stream $\left(\mathrm{S}_{07}\right)$ and biofertilizer stream $\left(\mathrm{S}_{08}\right)$ were estimated [51,52]. $\mathrm{CO}_{2}$ 
formed in the CHP unit was determined taking into account its fraction in the biogas stream.

\subsubsection{Energy Balance}

The stages of the process considered for this energy balance include microalgal cultivation, biomass harvesting, cell disruption and lipids extraction, for energy consumption, and the CHP unit, for energy production.

Regarding microalgal cultivation, energy consumption was considered at the following levels: open pond mixing, water pumping, and blowers for flue gas injection. The energy required to mix the HRP was determined assuming an average mixing velocity of $0.23 \mathrm{~m} \mathrm{~s}^{-1}$, according to Lundquist et al. [41] and Milledge et al. [53]. Major and minor head losses were also calculated. In this HRP, major head loss accrues from the friction at the bottom of the pond and can be calculated according to the Manning's equation. The Manning's roughness coefficient for clay channels was assumed as 0.018 , according to the literature [54]. For this reactor, two minor head losses were taken into account: (i) head loss from flow around both $180^{\circ}$ bends $\left(h_{b}\right)$ and (ii) head loss caused by the two carbonation sumps $\left(h_{\mathrm{s}}\right)$ in each pond. These were estimated according to the Darcy-Weisbach equation, assuming a kinetic loss coefficient of 1.5 for the $180^{\circ}$ bend and 4 for the carbonation sump. The power required for the mixing was then calculated, assuming a paddle wheel efficiency of $40 \%$ and an average diurnal and night period of $12 \mathrm{~h}$ [55]. The energy required for water pumping was determined considering the manometric head, the input flow $\left(\mathrm{S}_{01}\right)$, the specific effluent weight, and pump and motor efficiencies ( $88 \%$ and $83 \%$, respectively). The flow leaves the ponds by gravity. Based on the carbon requirements for microalgae in each scenario, and assuming a $7 \%(\mathrm{v} / \mathrm{v})$ concentration of $\mathrm{CO}_{2}$ in the flue gas, the energy required for the distribution of $\mathrm{CO}_{2}$ was estimated [56] considering an air blowers efficiency of $75 \%$ [57].

For biomass harvesting, the only energy requirement considered is the one for centrifugation. This energy consumption was determined considering the input flow $\left(\mathrm{S}_{03}\right)$, as well as the centrifuge specific energy consumption that, according to Milledge and Heaven [58], accounts for $1.4 \mathrm{kWh} \mathrm{m}^{-3}$.

Energy consumption in the cell disruption stage corresponds to the energy required for the PEF unit. Specific energy consumption for this equipment was considered to be $4 \mathrm{~kW} \mathrm{~m}^{-3}$, as reported by Flisar et al. [59]. Knowing this value and the input stream resulting from the harvesting process $\left(\mathrm{S}_{04}\right)$, the energy requirement was calculated.

Concerning the cogeneration unit, thermal and electrical energy are produced from the biogas formed in the AD. Energy production estimations were performed considering the gas flow rate that enters the $\mathrm{CHP}$ unit $\left(\mathrm{S}_{07}\right)$ and the biogas calorific value. According to the literature, a normal cubic meter of $\mathrm{CH}_{4}$ has a calorific value of $10 \mathrm{kWh}$ [60]. The energetic output was considered to be $40 \%$ for electrical energy and $45 \%$ for thermal energy [61].

\subsubsection{Economic Assessment}

To study the feasibility of implementing this biorefinery plant, for each scenario (i) the net present value (NPV), (ii) the discounted payback period (DPP), and (iii) the internal rate of return (IRR) were determined. NPV was determined considering the estimated annual capital investment, annual production costs, and the expected annual revenues from the explored products and services provided by the algal facility.

Capital investment, or fixed capital, corresponds to the total investment to create the biorefinery plant, including major equipment purchase, as well as all the direct and indirect costs associated with these. All main equipment was considered in this study: the HRPs, air blowers, clarifier, centrifuge, decanter, PEF unit, AD, and CHP unit. Equipment costs were determined based on values reported in the literature and updated using euro values for the year of 2019 using the Chemical Engineering Plant Cost Index (CEPCI), according to Equation (9):

$$
\text { Cost }_{2}=\text { Cost }_{1} \times \frac{\mathrm{CEPCI}_{2}}{\mathrm{CEPCI}_{1}}
$$


where 1 represents a year in time at which cost and the index value are known and 2 represents a year in time at which index value is known, but the cost is not. Total equipment acquisition cost was assumed to account for $85 \%$ of total investment costs. Direct costs included in this assessment are the piping system, yard improvements, equipment installation, instrumentation and control, support buildings, switchboards, and service facilities. The indirect costs include the construction expenses, the contractor's fee, contingency, and engineering and supervision [62]. For each of these investment components, a fraction of the total equipment purchase cost was assumed, according to information retrieved from the literature (see Table S1 from the Supplementary Material).

Regarding the production/operational costs, they can be divided into variable, fixed, and other costs. Variable costs include costs that may vary throughout the year, depending on seasonal productivity, e.g., raw materials, the miscellaneous materials, energy required for the plant operation, the amount of $\mathrm{NaOH}$ needed for the biomass thickening step, the amount of nitrogen $\left(\mathrm{NH}_{4} \mathrm{NO}_{3}\right)$ needed to guarantee an adequate $\mathrm{N}: \mathrm{P}$ molar ratio for microalgal growth, and shipping and packaging. Fixed costs do not depend on productivity fluctuation during the year. These expenses include equipment maintenance, operating labor, laboratory costs, supervision, plant overheads, insurance, local taxes, and royalties. For the investment costs, a percentage of the fixed capital or other costs was attributed to each of the mentioned components.

For the proposed biorefinery, the following revenues were assumed: (i) lipids extracted from microalgal biomass and sold to biodiesel production industries at $1 € \mathrm{~kg}^{-1}$; (ii) treatment of the paper industry effluent with a credit of $2.40 €$ per $\mathrm{kg}$ of phosphorus removed [63,64]; (iii) steam and electricity production in the CHP unit and sale at $0.14 € \mathrm{kWh}^{-1}[63,65]$; (iv) treatment of the sludge from the paper industry WWTP at $25 € \operatorname{ton}^{-1}$; (v) biofertilizer production in the anaerobic digestion stage, sold at $0.40 € \mathrm{~kg}^{-1}$ [65]; and (vi) $\mathrm{CO}_{2}$ uptake for microalgal growth, with a credit of $30 € \mathrm{t}^{-1}$ [64,66].

Considering the expenses and incomes, the project investment analysis was done considering a project time of 30 years. Inflation was assumed to be $1.5 \%$, according to the last values reported in PORDATA [67]. Corporate income tax (CIT) was considered $21 \%$, value-added tax (VAT) $10 \%$, working capital needs $5 \%$, and cost of capital $6 \%$ [68-70]. NPV was calculated by adding the present values of annual cash-flows, according to Equation (10):

$$
\mathrm{NPV}=\sum_{\mathrm{i}=0}^{\mathrm{n}} \frac{\mathrm{CF}_{\mathrm{i}}}{(1+\mathrm{r})^{\mathrm{i}}}
$$

where $\mathrm{CF}_{\mathrm{i}}$ is the cash flow in the year $\mathrm{i}$, and $\mathrm{r}$ is the interest rate. If the NPV is positive, then the project is viable because costs are lower than the net income. DPP corresponds to the number of years that takes to break even, which is when the net cash flows that are generated cover the initial investment of the proposed project. In this case, the DPP must be less than 30 years for the project to be viable. IRR is the annual rate of growth that an investment is estimated to generate. This parameter is determined using the same concept as the NPV, but in this one, the NPV is set to zero. The project is viable if the IRR is higher than the interest rate, so that there are more incomes than outcomes. The higher the IRR, the more attractive the project is for investors.

\subsubsection{Sustainability Assessment}

Two sustainability parameters were determined: (i) energy returned on energy invested (EROEI) and (ii) net $\mathrm{CO}_{2}$ balance. EROEI was determined considering the energy consumed and produced in each scenario, according to Equation (11):

$$
\text { EROEI }=\frac{\text { Energy produced in the microalgal facility }}{\text { Total energy required }}
$$

When the EROEI index is higher than one, the biorefinery is energy self-sustained, which means that it does not need to buy energy from the network. 
For the net $\mathrm{CO}_{2}$ balance, sources of consumption and production of $\mathrm{CO}_{2}$ were determined. On the one hand, microalgae uptake $\mathrm{CO}_{2}$ for their growth. This requirement was calculated taking into account the carbon removal rate, total cultivation area, and $\mathrm{CO}_{2}$ capture efficiency, which was assumed to be $80 \%[71,72]$. On the other hand, $\mathrm{CO}_{2}$ is released in the CHP unit.

\section{Results and Discussion}

\subsection{Paper Industry Effluent Remediation Using Microalgae: Experimental Work}

\subsubsection{Biomass Growth}

Figure 3 shows the biomass concentration over time for C. vulgaris grown under different paper industry effluent concentrations. It is possible to observe that this species has successfully grown in all culture medium compositions, which indicates that the evaluated paper industry effluent did not have an inhibitory effect on biomass growth. For all cultures, the microalgal lag phase was either inexistent or very short (less than one day). However, the duration of this phase increased with the increase in the effluent percentage, being more notorious in the cultures grown with $80 \%$ and $100 \%$ of effluent. These results seem to indicate that although the paper industry effluent was not inhibitory for microalgal growth, a longer adaptation period was required for higher effluent loads, which may be due to [72-74]: (i) the higher color intensity of the concentrated effluent (that can limit microalgal access to light); and (ii) the presence of lignin, humic acids, furans, dioxins, aluminum, and manganese, which can slow down microalgal growth and increase the lag period. Regarding the exponential growth phase, all cultures achieved the end of this phase before day 5 of the experiments. At the end of the cultivation period, almost all cultures were in the deceleration or stationary growth phase. In the assays with higher effluent percentage $(60 \%, 80 \%$, and $100 \%)$, it is possible to observe that higher biomass concentrations were achieved. Moreover, C. vulgaris growth behavior in these assays was similar to the one observed for the positive control assay $(\mathrm{C}+)$. The higher biomass concentrations achieved in these three assays may be explained by the fact that these culture medium compositions have higher nitrogen and phosphorus concentrations. With more nutrients available, microalgae grow and reproduce more and faster. For this same reason, the assays with a reduced concentration of effluent from the paper company-20\% and $40 \%$-resulted in lower biomass concentrations at the end of the experiments.

Table 2 shows the main growth parameters $\left(\mu, X_{\max }, P_{X, \max }, P_{X, a v g}\right)$ determined for C. vulgaris cultures. According to these data specific growth rate values ranged from $0.155 \pm 0.005$ to $0.33 \pm 0.07 \mathrm{~d}^{-1}$, the lowest growth rate being observed for the $20 \%$ assay and the highest for the $80 \%$ effluent assay. The specific growth rate determined for the positive control (modified OECD medium) was $0.299 \mathrm{~d}^{-1}$.

Regarding the maximum biomass concentration results, the assays with $60 \%$ and $100 \%$ of effluent were the ones presenting the highest value of $X_{\max }(495 \pm 2$ and $495 \pm 25 \mathrm{mg} \mathrm{DW} \mathrm{L}^{-1}$, respectively). On the other hand, the lowest value of this parameter was registered for the $20 \%$ effluent assay $\left(337 \pm 9 \mathrm{mg} \mathrm{DW} \mathrm{L}^{-1}\right)$. These results demonstrate once more that low concentrations of nutrients (mainly nitrogen and phosphorus) limit microalgal growth. For the positive control, the highest biomass concentration achieved was $(617 \pm 5) \mathrm{mg} \mathrm{DW} \mathrm{L}^{-1}$, which shows that, although $C$. vulgaris grew well in the paper industry effluent, better results can be achieved when biomass is grown in a synthetic growth medium, such as the modified OECD test medium. 


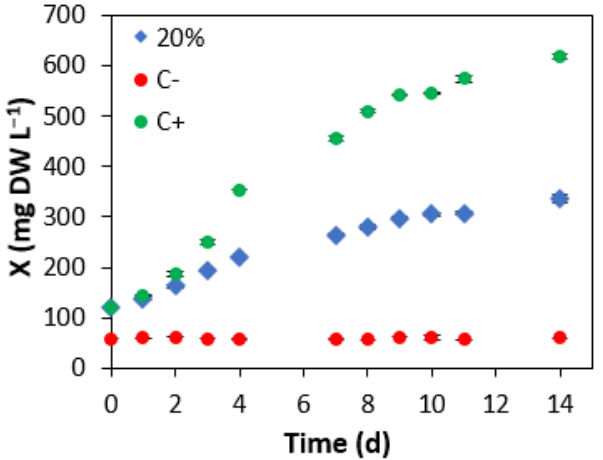

(a)

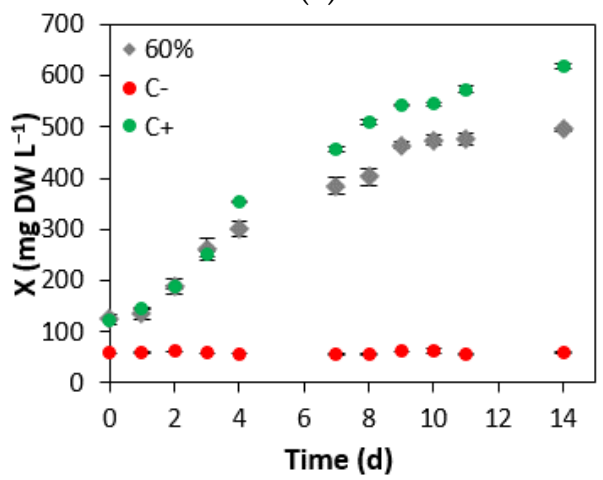

(c)

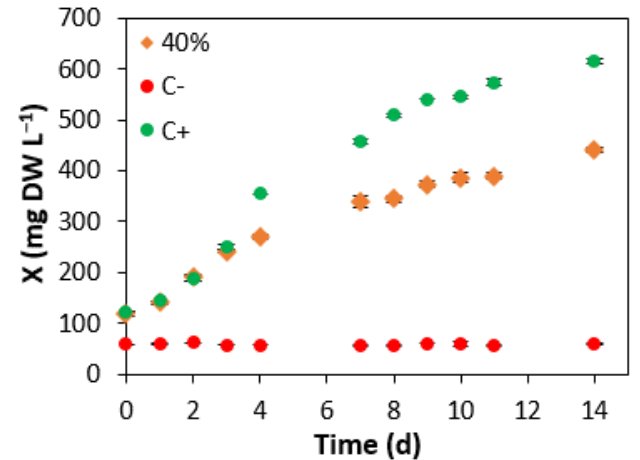

(b)

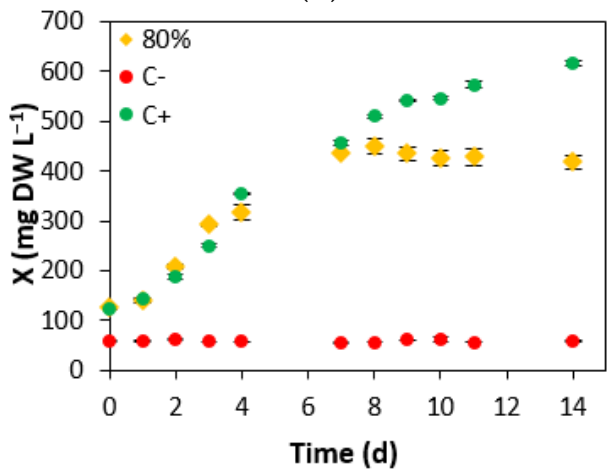

(d)

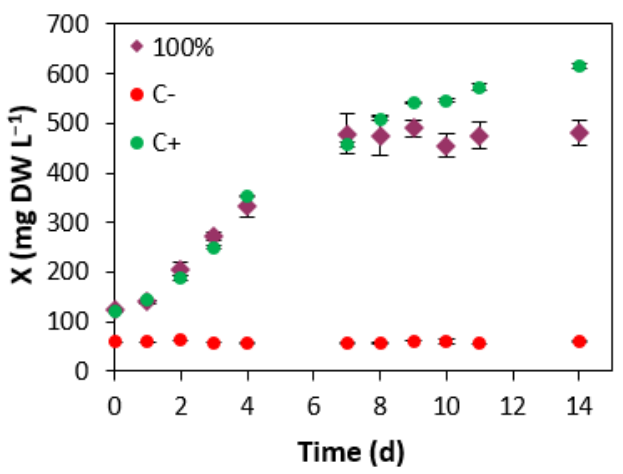

(e)

Figure 3. Growth curves obtained for C. vulgaris grown in the positive and negative controls and under different paper industry effluent compositions: (a) 20\% effluent; (b) 40\% effluent; (c) $60 \%$ effluent; (d) $80 \%$ effluent; and (e) $100 \%$ effluent. Error bars correspond to the standard deviation of the mean obtained from two independent experiments.

Table 2. Growth parameters obtained for C. vulgaris grown under different effluent compositions.

\begin{tabular}{|c|c|c|c|c|}
\hline Assays & $\begin{array}{c}\mu \\
\left(d^{-1}\right)\end{array}$ & 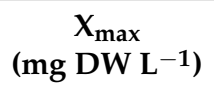 & $\begin{array}{c}P_{X, \max } \\
\left(\mathrm{mg} \mathrm{DW} \mathrm{L}^{-1} \mathrm{~d}^{-1}\right)\end{array}$ & $\begin{array}{c}P_{X, \text { avg }} \\
\left(\mathrm{mg} \mathrm{DW} \mathrm{L}^{-1} \mathrm{~d}^{-1}\right)\end{array}$ \\
\hline $20 \%$ & $0.155 \pm 0.005$ & $337 \pm 9$ & $31 \pm 2$ & $15.5 \pm 0.5$ \\
\hline $40 \%$ & $0.220 \pm 0.007$ & $440 \pm 3$ & $53 \pm 2$ & $23.0 \pm 0.5$ \\
\hline $60 \%$ & $0.27 \pm 0.01$ & $495 \pm 2$ & $73 \pm 7$ & $26 \pm 1$ \\
\hline $80 \%$ & $0.33 \pm 0.07$ & $448 \pm 19$ & $83 \pm 8$ & $20.8 \pm 0.9$ \\
\hline $100 \%$ & $0.288 \pm 0.002$ & $495 \pm 25$ & $74 \pm 2$ & $25 \pm 2$ \\
\hline Positive control (C+) & 0.299 & $617 \pm 5$ & $104 \pm 3$ & $35.4 \pm 0.2$ \\
\hline Negative control (C-) & - & $63 \pm 2$ & $4.6 \pm 0.9$ & $0.06 \pm 0.05$ \\
\hline
\end{tabular}

$\mu$-specific growth rate; $\mathrm{X}_{\max }$-maximum biomass concentration; $\mathrm{P}_{\mathrm{X}, \mathrm{max}}$-maximum biomass productivity; $\mathrm{P}_{\mathrm{X}, \mathrm{avg}}$-average biomass productivity; DW-dry weight. 
Concerning maximum biomass productivity values, the highest value was $83 \pm 8 \mathrm{mg} \mathrm{DW} \mathrm{L}^{-1} \mathrm{~d}^{-1}$ for the $80 \%$ effluent assay, as it would be expected, given that it was also in this assay that the highest specific growth rate was achieved. Still, the $P_{X, \max }$ value was slightly lower than the one obtained for the positive control, $104 \pm 3 \mathrm{mg} \mathrm{DW} \mathrm{L}^{-1} \mathrm{~d}^{-1}$, due to the color and presence of potentially inhibitory substances in the experiments dealing with real effluent compositions. Experiments with $60 \%$ and $100 \%$ effluent also showed high maximum biomass productivities $\left(73 \pm 7\right.$ and $74 \pm 2 \mathrm{mg} \mathrm{DW} \mathrm{L}^{-1} \mathrm{~d}^{-1}$, respectively). The $20 \%$ effluent test was the one that presented the lowest value for this parameter $\left(31 \pm 2 \mathrm{mg} \mathrm{DW} \mathrm{L}^{-1} \mathrm{~d}^{-1}\right)$, which is in line with the results presented so far.

Considering the average biomass productivity, the obtained values ranged from $15.5 \pm 0.5$ to $26 \pm 1 \mathrm{mg} \mathrm{DW} \mathrm{L}^{-1} \mathrm{~d}^{-1}$. Contrary to what was observed for specific growth rates and maximum biomass productivities, the assays with $60 \%$ and $100 \%$ of effluent registered the highest values of $\mathrm{P}_{\mathrm{X}, \text { avg }}$ : $26 \pm 1$ and $25 \pm 2 \mathrm{mg} \mathrm{DW} \mathrm{L}^{-1} \mathrm{~d}^{-1}$, respectively. Since the $80 \%$ assay registered the highest values of specific growth rate, it reached the stationary and death phases faster, leading to negative productivities at the end of the experiment and, consequently, to lower average biomass productivities, when compared to the $40 \%, 60 \%$, and $100 \%$ assays. In the positive control, there was still a significant increase in biomass concentration at the end of the 14-day experiments, meaning that C. vulgaris did not reach the stationary growth phase during this period. Therefore, the average biomass productivity in this control $\left(35.4 \pm 0.2 \mathrm{mg} \mathrm{DW} \mathrm{L}^{-1} \mathrm{~d}^{-1}\right)$ was significantly higher than those obtained in the $60 \%$ and $100 \%$ assays.

Although some authors have studied the potential of microalgae for contaminants removal from paper industry effluents, only a few studies have evaluated microalgal growth behavior, some examples being represented in Table 3 . When growing the microalga Nannochloropsis oculata in effluents resulting from pulp and paper industry for eicosapentaenoic acid production, Polishchuk et al. [74] determined a specific growth rate of $0.405 \mathrm{~d}^{-1}$. This value was higher than the values reported in the present study, which may be related with the higher nutrients concentrations (especially nitrogen and phosphorus) supplied in the reference study. Moreover, the microalga N. oculata may exhibit higher tolerance to this effluent type, achieving higher growth rates. In the study performed by Tao et al. [72], maximum biomass concentrations determined for C. vulgaris and Scenedesmus acuminatus grown in paper industry effluents were 291 and $822 \mathrm{mg} \mathrm{DW} \mathrm{L}^{-1}$, respectively. Maximum biomass concentrations determined for C. vulgaris in the present study were higher than those reported by the authors, which confirms that the studied effluent did not have an acute inhibitory effect on C. vulgaris growth. In the case of S. acuminatus, the higher biomass concentrations may be associated with the higher ability of this microalga to grow in the paper industry effluent. More recently, Porto et al. [47] evaluated C. vulgaris growth in different concentrations of an effluent resulting from a Portuguese paper company, determining the following growth parameters: (i) specific growth rates ranging between 0.093 and $0.16 \mathrm{~d}^{-1}$; (ii) maximum biomass concentrations ranging between 136 and $249 \mathrm{mg} \mathrm{DW} \mathrm{L}^{-1}$; and (iii) average biomass productivities ranging between 6.22 and $16 \mathrm{mg} \mathrm{DW} \mathrm{L} \mathrm{L}^{-1} \mathrm{~d}^{-1}$. All parameters determined in this study were considerably lower than those obtained in the present study, which may be associated with a higher inhibitory effect of the effluent used in the reference study and also with the cultivation conditions. For example, in the study performed by Porto et al. [47], the cultures were supplied with a PAR of 30-40 $\mu \mathrm{mol} \mathrm{m} \mathrm{m}^{-2} \mathrm{~s}^{-1}$, whereas in this study, a PAR of $202.9 \mu \mathrm{mol} \mathrm{m}^{-2} \mathrm{~s}^{-1}$ was used, indicating a possible limitation by light in the reference study. 
Table 3. Microalgal growth and nutrients uptake parameters determined in this study and other studies reporting microalgal growth in paper industry effluents.

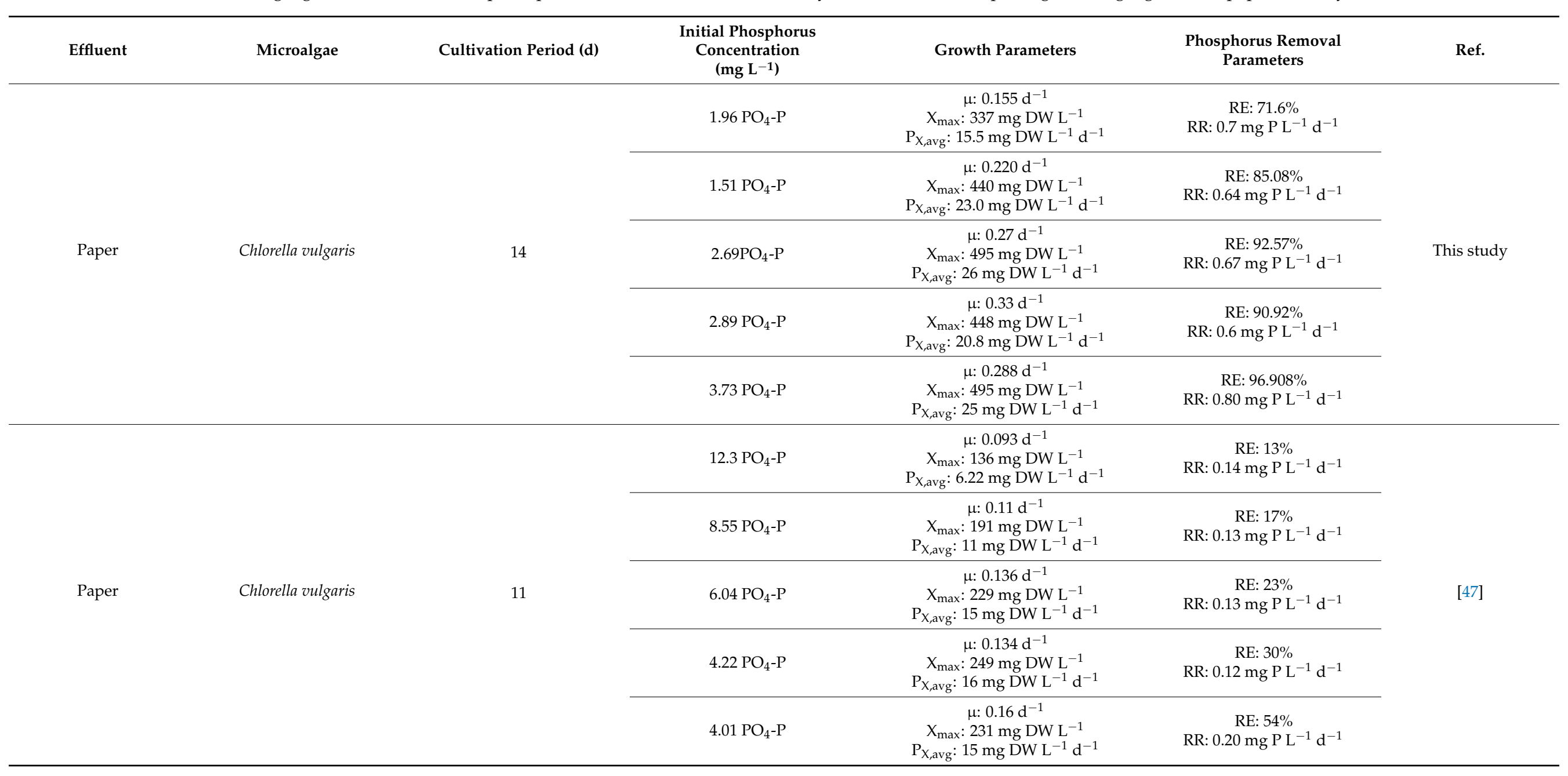


Table 3. Cont

\begin{tabular}{|c|c|c|c|c|c|c|}
\hline Effluent & Microalgae & Cultivation Period (d) & $\begin{array}{l}\text { Initial Phosphorus } \\
\text { Concentration } \\
\left(\mathrm{mg} \mathrm{L}^{-1}\right)\end{array}$ & Growth Parameters & $\begin{array}{c}\text { Phosphorus Removal } \\
\text { Parameters }\end{array}$ & Ref. \\
\hline Pulp and paper mill & Chlorella vulgaris & 14 & $8.00 \mathrm{PO}_{4}-\mathrm{P}$ & $X_{\max }: 291 \mathrm{mg} \mathrm{DW} \mathrm{L}{ }^{-1}$ & RE: $>97 \%$ & [72] \\
\hline Paper mill & Scenedesmus sp. & 28 & $9.86 \mathrm{PO}_{4}-\mathrm{P}$ & - & $\begin{array}{c}\text { RE: } 71 \% \\
\text { RR: } 0.25 \mathrm{mg} \mathrm{P} \mathrm{L}^{-1} \mathrm{~d}^{-1}\end{array}$ & [75] \\
\hline \multirow{3}{*}{$\begin{array}{l}\text { Pulp and paper with } \\
\text { dairy sludge and } \\
\text { municipal }\end{array}$} & Scenedesmus sp. & \multirow{3}{*}{6} & $10.1 \mathrm{PO}_{4}-\mathrm{P}$ & - & $\begin{array}{c}\text { RE: } 96-98 \% \\
\text { RE: } 1.7 \mathrm{mg} \mathrm{P} \mathrm{L}^{-1} \mathrm{~d}^{-1}\end{array}$ & \multirow{3}{*}{ [76] } \\
\hline & Scenedesmus dimorphus & & $2.99 \mathrm{PO}_{4}-\mathrm{P}$ & - & $\begin{array}{c}\text { RE: } 90-94 \% \\
\text { RR: } 0.46 \mathrm{mg} \mathrm{P} \mathrm{L}^{-1} \mathrm{~d}^{-1}\end{array}$ & \\
\hline & Selenastrum minutum & & $1.60 \mathrm{PO}_{4}-\mathrm{P}$ & - & $\begin{array}{c}\text { RE: } 97 \% \\
\text { RR: } 0.26 \mathrm{mg} \mathrm{P} \mathrm{L}{ }^{-1} \mathrm{~d}^{-1}\end{array}$ & \\
\hline
\end{tabular}

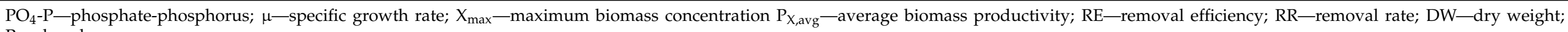

$\mathrm{P}$-phosphorus. 


\subsubsection{Nutrient Removal}

The time-course evolution of phosphorus concentration in the different tested conditions is shown in Figure 4. Analysis of this figure demonstrates that $C$. vulgaris successfully removed phosphorus from all tested culture medium compositions. At the end of the 14th day, the final phosphorus concentrations varied between $0.12 \pm 0.01$ and $0.5 \pm 0.3 \mathrm{mg} \mathrm{P} \mathrm{L}^{-1}$. Since these values are lower than the phosphorus discharge limit established by APA ( $0.8 \mathrm{mg} \mathrm{P} \mathrm{L}^{-1}$, or $0.5 \mathrm{mg} \mathrm{P} \mathrm{L}^{-1}$ at exceptional periods of the year), it is possible to confirm the potential of this species for the treatment of secondary-treated effluents resulting from the paper industry. The lowest value of phosphorus registered at the end of the experiments was obtained for the $100 \%$ effluent assay, whereas the highest was obtained at $20 \%$. For more accurate quantification of the potential of $C$. vulgaris for phosphorus removal from a paper industry effluent, some removal parameters were determined: $R E(\%), R R\left(\mathrm{mg} \mathrm{P} \mathrm{L}^{-1} \mathrm{~d}^{-1}\right), \mathrm{MR}\left(\mathrm{mg} \mathrm{P} \mathrm{L}^{-1}\right)$, and $\mathrm{Y}_{\mathrm{X} / \mathrm{P}}\left(\mathrm{g} \mathrm{DW} \mathrm{g}^{-1} \mathrm{P}\right)$. These results are presented in Table 4 .

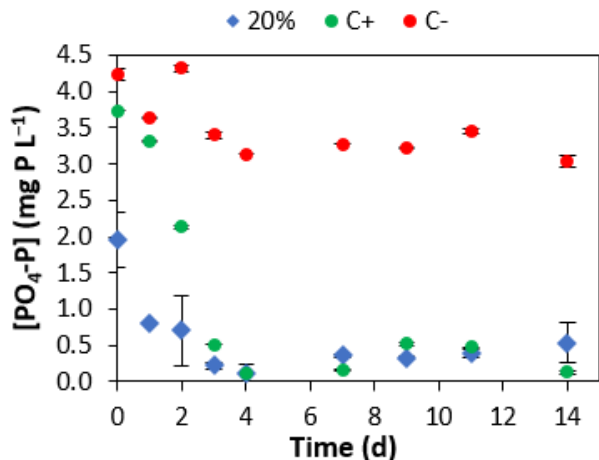

(a)

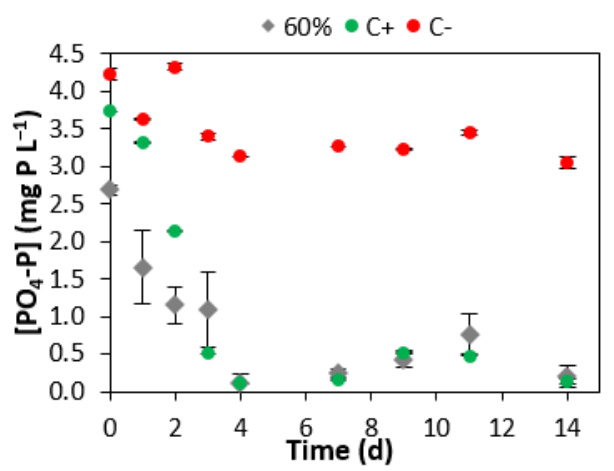

(c)

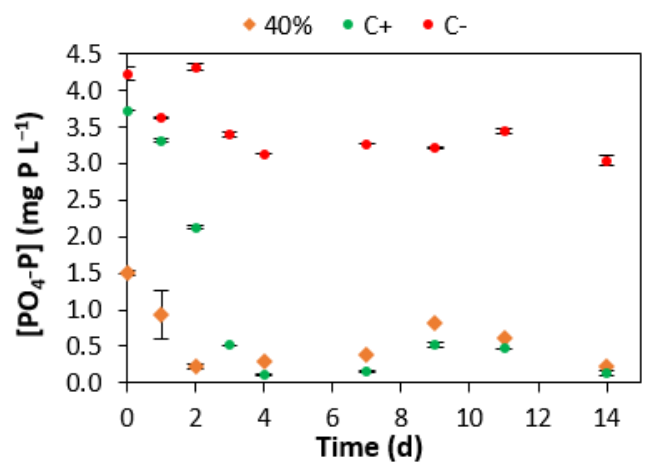

(b)

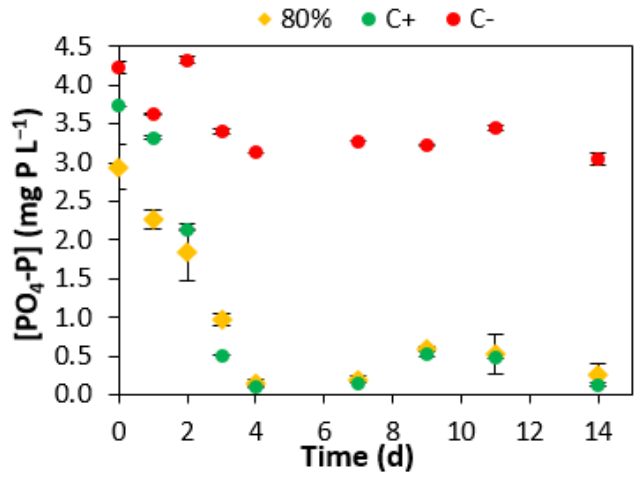

(d)

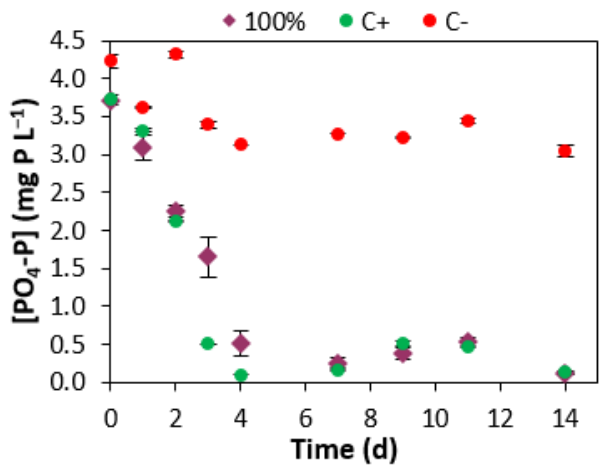

(e)

Figure 4. Phosphorus concentration variation over time for C. vulgaris grown in the positive and negative controls and under different paper industry effluent compositions: (a) 20\% effluent; (b) 40\% effluent; (c) 60\% effluent; (d) 80\% effluent; and (e) $100 \%$ effluent. Error bars correspond to the standard deviation of the mean obtained from two independent experiments. 
Table 4. Phosphorus removal parameters obtained for C. vulgaris grown under different effluent compositions.

\begin{tabular}{|c|c|c|c|c|}
\hline Assays & $\begin{array}{l}\mathrm{RE} \\
(\%)\end{array}$ & $\begin{array}{c}R R \\
\left(\mathrm{mg} \mathrm{P} \mathrm{L} \mathrm{L}^{-1} \mathrm{~d}^{-1}\right)\end{array}$ & $\begin{array}{c}\mathrm{MR} \\
\left(\mathrm{mg} \mathrm{P} \mathrm{L}^{-1}\right)\end{array}$ & $\begin{array}{c}\mathrm{Y}_{\mathrm{X} / \mathrm{P}} \\
\left(\mathrm{g} D W \mathrm{~g}^{-1} \mathrm{P}\right)\end{array}$ \\
\hline $20 \%$ & $71.6 \pm 0.2$ & $0.7 \pm 0.1$ & $1.4 \pm 0.6$ & $34 \pm 7$ \\
\hline $40 \%$ & $85.08 \pm 0.07$ & $0.64 \pm 0.02$ & $1.3 \pm 0.1$ & $59 \pm 1$ \\
\hline $60 \%$ & $92.57 \pm 0.07$ & $0.67 \pm 0.03$ & $2.5 \pm 0.2$ & $65 \pm 6$ \\
\hline $80 \%$ & $90.92 \pm 0.07$ & $0.6 \pm 0.3$ & $2.7 \pm 0.5$ & $70 \pm 4$ \\
\hline $100 \%$ & $96.908 \pm 0.003$ & $0.80 \pm 0.04$ & $3.60 \pm 0.06$ & $64 \pm 3$ \\
\hline Positive control $(\mathrm{C}+)$ & $96.515 \pm 0.008$ & $0.906 \pm 0.002$ & $3.60 \pm 0.03$ & $64.18 \pm 0.05$ \\
\hline Negative control $(\mathrm{C}-)$ & $28.018 \pm 0.004$ & $0.0846 \pm 0.0005$ & $1.185 \pm 0.007$ & $0.7 \pm 0.5$ \\
\hline
\end{tabular}

RE-removal efficiency; RR—removal rate; $M R$-mass removal per unit of volume; $\mathrm{Y}_{\mathrm{X} / \mathrm{P}}$-specific biomass yield based on phosphorus consumption; P-phosphorus; DW—dry weight.

Regarding the removal efficiencies, the obtained values ranged between $71.6 \pm 0.2$ and $96.9 \pm 0.1 \%$, indicating that there is substantial phosphorus removal, particularly in the experiments performed with the highest effluent loads: the highest removal efficiency was obtained for the $100 \%$ effluent assay, this value being very close to the one achieved in the positive control $(96.5 \%)$. These results are in agreement with the results obtained for the growth parameters and biomass growth curves.

Phosphorus removal rate values ranged between $0.6 \pm 0.3$ and $0.80 \pm 0.04 \mathrm{mg} \mathrm{P} \mathrm{L}^{-1} \mathrm{~d}^{-1}$. Again, the highest value was obtained for the $100 \%$ effluent assay, but the lowest value for the $80 \%$ assay. The lowest value would be expected to be registered for the $20 \%$ assay. However, the range of values obtained for this parameter is relatively small, meaning that all values determined in the different culture conditions are very similar. Concerning the mass removal values per unit of volume, a higher removal of phosphate-phosphorus was observed in the experiments carried out with $100 \%$ effluent $\left(3.60 \pm 0.06 \mathrm{mg} \mathrm{P} \mathrm{L}^{-1}\right)$, this value being the same as the one registered for the positive control. These results are not surprising, due to the higher phosphorus concentrations supplied in these experiments. The similar behavior between both conditions was also expected because both nitrogen and phosphorus were supplied in similar amounts. As it was also predictable, the lowest values of mass removal per unit of volume were determined in the $20 \%$ and $40 \%$ effluent assays: $1.4 \pm 0.6$ and $1.3 \pm 0.1 \mathrm{mg} \mathrm{P} \mathrm{L}^{-1}$, respectively. Regarding the specific biomass yields, the range of values calculated, $34 \pm 7$ to $70 \pm 4 \mathrm{~g} \mathrm{DW} \mathrm{g}^{-1} \mathrm{P}$, is lower than those reported by Pereira et al. [77] (20-150 $\left.\mathrm{g} \mathrm{DW} \mathrm{g}^{-1} \mathrm{P}\right)$ and Silva et al. [78] (37.0-150.2 $\left.\mathrm{g} \mathrm{DW} \mathrm{g}^{-1} \mathrm{P}\right)$. The value obtained for the test with $100 \%$ paper industry effluent $\left(64 \pm 3 \mathrm{~g} \mathrm{DW} \mathrm{g}^{-1} \mathrm{P}\right)$ was lower than the one from the $80 \%$ assay and practically the same as the one obtained in the $60 \%$ assay: $70 \pm 4$ and $65 \pm 6 \mathrm{~g} \mathrm{DW} \mathrm{g}^{-1} \mathrm{P}$, respectively. These results indicate that, for the same amount of phosphorus, the cultures grown with $80 \%$ of effluent produce more biomass, and cultures grown with $60 \%$ effluent produce practically the same biomass as the ones grown with $100 \%$ effluent.

Phosphorus removal from paper industry effluents has already been reported in the literature. Table 3 summarizes some of the obtained values. According to these data, it is possible to observe that phosphorus removal efficiencies and removal rates obtained in the present study were in the same order of magnitude as those reported in the studies performed by Gentili [76] and Tao et al. [72]. In the study performed by Gentili [76], cultivation of the microalgae Scenedesmus sp., Scenedesmus dimorphus, and Selenastrum minutum in mixtures of pulp and paper industry effluents with municipal and dairy ones resulted in phosphate-phosphorus removal efficiencies ranging from 90 to $98 \%$ and in average removal rates of $0.26-1.7 \mathrm{mg} \mathrm{P} \mathrm{L}^{-1} \mathrm{~d}^{-1}$. More recently, in the study carried out by Tao et al. [72], phosphorus removal efficiencies higher than $97 \%$ were determined for the microalgae C. vulgaris and S. acuminatus. These results indicate the potential of $C$. vulgaris for phosphorus removal from paper industry effluents, provided that the adequate culturing conditions (e.g., non-limiting and non-inhibitory light conditions, adequate N:P molar ratios, among others) are supplied. This was confirmed by the higher 
removal efficiencies and removal rates determined in this study when compared to the ones obtained in a previous study performed by Porto et al. [47], where the authors concluded that microalgal uptake efficiencies could have been improved by modulating microalgal culturing conditions, such as light intensity, temperature, and $\mathrm{pH}$.

\subsection{Microalgal-Based Biorefinery for Paper Industry Effluent Remediation: Techno-Economic and Sustainability Assessment}

\subsubsection{Mass Balance}

Table 5 shows all input and output streams determined in the mass balance step. HRP output streams vary from 1.6 to $4.7 \times 10^{4} \mathrm{~m}^{3} \mathrm{~d}^{-1}$, the lowest value being registered in Scenario 2 and the highest value in Scenario 3. As biomass productivity is higher in Scenario 3, and lower in Scenario 2, a higher input flow is required in Scenario 3 to satisfy the high nutrients requirements and, on the other hand, a lower input flow is required in Scenario 2. In all the other scenarios, where a $2 \%$ PE was assumed, a $S_{02}$ flow rate of $3.1 \times 10^{4} \mathrm{~m}^{3} \mathrm{~d}^{-1}$ was obtained. For this same reason, the highest $S_{W R}$ and $S_{P E}$ streams values were obtained in Scenario $3\left(\mathrm{~S}_{\mathrm{WR}}-1.3 \times 10^{4} \mathrm{~m}^{3} \mathrm{~d}^{-1}, \mathrm{~S}_{\mathrm{PE}}-3.7 \times 10^{4} \mathrm{~m}^{3} \mathrm{~d}^{-1}\right)$ and the lowest values in Scenario $2\left(S_{W R}-0.59 \times 10^{4} \mathrm{~m}^{3} \mathrm{~d}^{-1}, \mathrm{~S}_{\mathrm{PE}}-1.2 \times 10^{4} \mathrm{~m}^{3} \mathrm{~d}^{-1}\right)$. In the base scenario, a $\mathrm{S}_{\mathrm{WR}}$ flow rate of $0.93 \times 10^{4} \mathrm{~m}^{3} \mathrm{~d}^{-1}$ and a $S_{P E}$ of $2.5 \times 10^{4} \mathrm{~m}^{3} \mathrm{~d}^{-1}$ were determined. These results are in line with the obtained nutrients removal rates and input concentrations, which are summarized in Table 6. The theoretical nitrogen, phosphorus, and carbon removal rates in the base scenario are $0.82,0.075$, and $6.8 \mathrm{~g} \mathrm{~m}^{-2} \mathrm{~d}^{-1}$, respectively. Carbon removal rates are higher because carbon is the major constituent of microalgae, representing $43 \%$ of biomass dry weight, according to C. vulgaris elemental composition.

Table 5. Mass balance results for each scenario.

\begin{tabular}{|c|c|c|c|c|c|c|c|}
\hline Streams Description & Sc 1 & Sc 2 & Sc 3 & Sc 4 & Sc 5 & Sc 6 & Sc 7 \\
\hline $\mathrm{S}_{01}$ : Water (medium) input in the open pond $\left(\times 10^{4} \mathrm{~m}^{3} \mathrm{~d}^{-1}\right)$ & 3.4 & 1.8 & 5.0 & 3.4 & 3.4 & 3.4 & 3.4 \\
\hline $\mathrm{S}_{02}$ : Biomass flow rate after cultivation $\left(\times 10^{4} \mathrm{~m}^{3} \mathrm{~d}^{-1}\right)$ & 3.1 & 1.6 & 4.7 & 3.1 & 3.1 & 3.1 & 3.1 \\
\hline $\mathrm{S}_{03}$ : Biomass flow rate after pre-concentration $\left(\times 10^{3} \mathrm{~m}^{3} \mathrm{~d}^{-1}\right)$ & 7.8 & 3.9 & 12 & 7.8 & 7.8 & 7.8 & 7.8 \\
\hline $\mathrm{S}_{04}$ : Biomass flow rate after centrifugation $\left(\mathrm{m}^{3} \mathrm{~d}^{-1}\right)$ & 75 & 37 & 112 & 75 & 75 & 75 & 75 \\
\hline Evaporation flow rate $\left(\times 10^{2} \mathrm{~m}^{3} \mathrm{~d}^{-1}\right)$ & 25 & 25 & 25 & 25 & 25 & 25 & 25 \\
\hline $\mathrm{S}_{05}$ : Extracted lipids flow rate $\left(\mathrm{m}^{3} \mathrm{~d}^{-1}\right)$ & 3.2 & 1.6 & 4.8 & 2.6 & 3.9 & 3.2 & 3.2 \\
\hline $\mathrm{S}_{06}$ : Biomass flow rate after lipids extraction $\left(\mathrm{m}^{3} \mathrm{~d}^{-1}\right)$ & 71 & 36 & 107 & 72 & 70 & 71 & 71 \\
\hline $\mathrm{S}_{07}$ : Biogas flow rate after anaerobic digestion $\left(\mathrm{t} \mathrm{d}^{-1}\right)$ & 4.9 & 2.5 & 7.4 & 5.1 & 4.7 & 3.3 & 6.5 \\
\hline $\begin{array}{l}\mathrm{S}_{08} \text { : Residue from the anaerobic digestion (biofertilizer) flow rate } \\
\qquad\left(\mathrm{t} \mathrm{d}^{-1}\right)\end{array}$ & 66 & 33 & 99 & 66 & 66 & 68 & 64 \\
\hline $\mathrm{S}_{09}:$ Sludge from the paper industry flow rate $\left(\mathrm{t} \mathrm{d}^{-1}\right)$ & 55 & 101 & 8.4 & 54 & 56 & 55 & 55 \\
\hline $\begin{array}{l}S_{P E}: \text { Paper industry effluent flow rate required for microalgal } \\
\text { growth }\left(\times 10^{4} \mathrm{~m}^{3} \mathrm{~d}^{-1}\right)\end{array}$ & 2.5 & 1.2 & 3.7 & 2.5 & 2.5 & 2.5 & 2.5 \\
\hline $\begin{array}{l}\mathrm{S}_{\mathrm{WR}} \text { : Recycling water flow rate required for microalgal growth } \\
\qquad\left(\times 10^{4} \mathrm{~m}^{3} \mathrm{~d}^{-1}\right)\end{array}$ & 0.93 & 0.59 & 1.3 & 0.93 & 0.93 & 0.93 & 0.93 \\
\hline $\mathrm{S}_{\mathrm{ED}}$ : Flow rate of the discharged effluent $\left(\times 10^{4} \mathrm{~m}^{3} \mathrm{~d}^{-1}\right)$ & 2.2 & 0.98 & 3.4 & 2.2 & 2.2 & 2.2 & 2.2 \\
\hline
\end{tabular}

Table 6. Removal rates determined for nitrogen, phosphorus, and carbon, and minimum concentrations of these nutrients required for microalgal growth in each scenario.

\begin{tabular}{|c|c|c|c|c|c|c|c|}
\hline Nutrients Removal Rates and Input Concentration & Sc 1 & Sc 2 & Sc 3 & Sc 4 & Sc 5 & Sc 6 & Sc 7 \\
\hline $\mathrm{RR}_{\mathrm{N}}\left(\mathrm{g} \mathrm{m}^{-2} \mathrm{~d}^{-1}\right)$ & 0.82 & 0.41 & 1.2 & 0.82 & 0.82 & 0.82 & 0.82 \\
\hline$N\left(\mathrm{mg} \mathrm{L}^{-1}\right)$ & 27 & 25 & 28 & 27 & 27 & 27 & 27 \\
\hline $\operatorname{RR}_{\mathrm{P}}\left(\mathrm{g} \mathrm{m}^{-2} \mathrm{~d}^{-1}\right)$ & 0.075 & 0.037 & 0.11 & 0.075 & 0.075 & 0.075 & 0.075 \\
\hline $\mathrm{P}\left(\mathrm{mg} \mathrm{L}^{-1}\right)$ & 2.4 & 2.3 & 2.5 & 2.4 & 2.4 & 2.4 & 2.4 \\
\hline $\operatorname{RR}_{C}\left(\mathrm{~g} \mathrm{~m}^{-2} \mathrm{~d}^{-1}\right)$ & 6.8 & 3.4 & 10 & 6.8 & 6.8 & 6.8 & 6.8 \\
\hline$C\left(t^{-1}\right)$ & 31 & 16 & 47 & 31 & 31 & 31 & 31 \\
\hline
\end{tabular}

$\mathrm{RR}_{\mathrm{N}}$-nitrogen removal rate; $\mathrm{N}-$ minimum nitrogen concentration required; $\mathrm{RR}_{\mathrm{P}}-$ phosphorus removal rate; $\mathrm{P}-$ minimum phosphorus concentration required; $\mathrm{RR}_{\mathrm{C}}-$ carbon removal rate; $\mathrm{C}-$ minimum carbon concentration required. 
Considering the streams resulting from the harvesting steps, $\mathrm{S}_{03}$ and $\mathrm{S}_{04}$, the values determined for the base scenario were $7.8 \times 10^{3}$ and $75 \mathrm{~m}^{3} \mathrm{~d}^{-1}$, respectively. The decrease in flow rate at the end of the dewatering step results from an increase in the biomass concentration from 2 to $200 \mathrm{~g} \mathrm{~L}^{-1}$. Knowing the volume of water collected in these two harvesting stages and the one required to satisfy the nutrients input concentrations in each scenario, it was possible to calculate the value of the discharged $\left(\mathrm{S}_{\mathrm{ED}}\right)$ stream: $2.2 \times 10^{4} \mathrm{~m}^{3} \mathrm{~d}^{-1}$ in Scenario 1. Lipids extraction stream $\left(\mathrm{S}_{05}\right)$ in Scenarios 1, 4, and 5 ranged between 2.6 and $3.9 \mathrm{~m}^{3} \mathrm{~d}^{-1}$. The lowest value from this range was registered in Scenario 4, which presented a PEF efficiency of 60\%, and the highest in Scenario 5, where a $90 \%$ extraction efficiency was assumed. However, considering all studied scenarios, the highest value was obtained in the third scenario $\left(4.8 \mathrm{~m}^{3} \mathrm{~d}^{-1}\right)$, due to the higher PE defined in this scenario, and, hence, to the higher biomass productivity and greater accumulation of the target product observed in these conditions. For the same reason, the lowest value $\left(1.6 \mathrm{~m}^{3} \mathrm{~d}^{-1}\right)$ was determined in the second scenario, the one presenting the lowest PE. It is also possible to observe that lower PEF efficiencies, which result in lower lipids extraction, lead to higher biomass flows after the lipids extraction $\left(\mathrm{S}_{06}\right)$. For the anaerobic digestion step, three different efficiencies of this process were evaluated: 45,30 , and $60 \%$, in Scenarios 1,6 , and 7 , respectively. The results of the mass balance step showed that the biogas flow rate was higher in Scenario $7\left(6.5 \mathrm{t} \mathrm{d}^{-1}\right)$ and lower in Scenario $6\left(3.3 \mathrm{t} \mathrm{d}^{-1}\right)$. Regarding the biofertilizer stream $\left(\mathrm{S}_{08}\right)$, values obtained in Scenarios 1, 6, and 7 were, respectively, 66, 68, and $64 \mathrm{td}^{-1}$. Scenarios with a more efficient anaerobic digestion have a higher conversion of organic matter into gases and, therefore, have fewer residues resulting from this process.

\subsubsection{Energy Balance}

This step of the TEA allowed the evaluation of the electrical requirements and profits of each of the studied scenarios, the results of which are shown in Table 7. Energy requirements for the cultivation, harvesting, and lipids extraction steps were the same for Scenarios $1,4,5,6$, and 7, being $5.8 \times 10^{3}, 11 \times 10^{3}$, and $7.1 \times 10^{3} \mathrm{kWh} \mathrm{d}^{-1}$, respectively. Although the PEF unit efficiencies were different between Scenarios 1, 4, and 5, no variation was observed between the results of the energy consumption in the extraction step, because the value only depends on the unit input flow $\left(\mathrm{S}_{04}\right)$ and on the specific energy consumption of the equipment, which was considered to be the same in all the studied scenarios. Regarding the energy obtained from the lipids extracted in these three scenarios, a positive and negative variation of $20 \%$ was observed between the results in Scenarios 1 and 5 and 1 and 4 , respectively. Concerning the electrical and thermal energy produced in the CHP unit in Scenarios 1, 6, and 7, it is possible to conclude that there was greater energy production (electrical and thermal) in the scenario with higher anaerobic digestion efficiency $\left(1.3 \times 10^{4}\right.$ and $1.5 \times 10^{4} \mathrm{kWh} \mathrm{d}^{-1}$ ), and less energy formed in the scenario with lower efficiency $\left(0.65 \times 10^{4}\right.$ and $\left.0.73 \times 10^{4} \mathrm{kWh} \mathrm{d}^{-1}\right)$. From the different microalgal production steps, harvesting, which includes the energy consumed during centrifugation, is the one with the greatest weight in terms of the energy consumed in the biorefinery, representing 46 , 39 , and $49 \%$ of all the energy consumed in Scenarios 1, 2, and 3, respectively. On the other hand, cultivation has the lowest impact on the overall energy consumption of the proposed biorefinery, except for Scenario 2.

Table 7. Energy balance results for each scenario.

\begin{tabular}{|c|c|c|c|c|c|c|c|}
\hline Energy Streams & Sc 1 & Sc 2 & Sc 3 & Sc 4 & Sc 5 & Sc 6 & Sc 7 \\
\hline 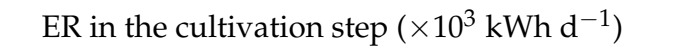 & 5.8 & 5.0 & 6.5 & 5.8 & 5.8 & 5.8 & 5.8 \\
\hline 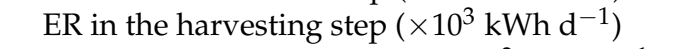 & 11 & 5.5 & 16 & 11 & 11 & 11 & 11 \\
\hline 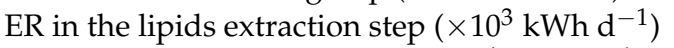 & 7.1 & 3.6 & 11 & 7.1 & 7.1 & 7.1 & 7.1 \\
\hline EO from the extracted lipids $\left(\times 10^{4} \mathrm{kWh}^{-1}\right)$ & 3.0 & 1.5 & 4.4 & 2.3 & 3.5 & 3.0 & 3.0 \\
\hline Electrical EP in the CHP unit $\left(\times 10^{4} \mathrm{kWh}^{-1}\right)$ & 0.97 & 0.49 & 1.5 & 1.1 & 0.93 & 0.65 & 1.3 \\
\hline Thermal EP in the CHP unit $\left(\times 10^{4} \mathrm{kWh}^{-1}\right)$ & 1.1 & 0.55 & 1.6 & 1.2 & 1.0 & 0.73 & 1.5 \\
\hline
\end{tabular}




\subsubsection{Economic Assessment}

Table 8 shows all the costs associated with equipment purchase and physical plant construction (capital investment). Total equipment cost ranged between 7.2 and 8.4 million euros, and capital investment between 18.0 and 21.2 million euros, the lowest values being determined in Scenario 2 and the highest in Scenario 3, due to the higher PE assumed in this scenario. When compared with the base scenario (Scenario 1), there was a relative increase of $20 \%$ in the total capital investment of Scenario 3, and a relative decrease of $7 \%$ in the result obtained in Scenario 2.

Table 8. Total capital investment (in $\mathrm{k} €$ ) determined for each scenario.

\begin{tabular}{cccccccc}
\hline Capital Investment & Sc 1 & Sc 2 & Sc 3 & Sc 4 & Sc 5 & Sc 6 & Sc 7 \\
\hline Direct costs & & & & & & & \\
Total purchase cost & 7739 & 7173 & 8447 & 7739 & 7739 & 7739 & 7739 \\
Equipment installation & 1548 & 1435 & 1689 & 1548 & 1548 & 1548 & 1548 \\
Instrumentation and control & 1161 & 1076 & 1267 & 1161 & 1161 & 1161 & 1161 \\
Piping & 1548 & 1435 & 1689 & 1548 & 1548 & 1548 & 1548 \\
Electrical & 774 & 717 & 845 & 774 & 774 & 774 & 774 \\
Buildings & 1161 & 1076 & 1267 & 1161 & 1161 & 1161 & 1161 \\
Yard improvements & 387 & 359 & 422 & 387 & 387 & 387 & 387 \\
Service facilities & 1548 & 1435 & 1689 & 1548 & 1548 & 1548 & 1548 \\
Indirect costs & & & & & & & \\
Engineering and supervision & 2322 & 2152 & 2534 & 2322 & 2322 & 2322 & 2322 \\
Construction expenses & 387 & 359 & 422 & 387 & 387 & 387 & 387 \\
Contractor's fee & 232 & 215 & 253 & 232 & 232 & 232 & 232 \\
Contingency & 619 & 574 & 676 & 619 & 619 & 619 & 619 \\
\hline Total $(k €)$ & 19,426 & 18,004 & 21,202 & 19,426 & 19,426 & 19,426 & 19,426 \\
\hline
\end{tabular}

Table 9 presents the results obtained for expenses associated with microalgal production in the proposed biorefinery, showing both variable and fixed costs. From all the costs associated with the production process, utilities present the highest impact on the value of the total expenses. That is in line with what was expected, since the utilities in this study account for the electrical energy required for the well-functioning of the biorefinery. On the other hand, laboratory and supervision costs represent the smallest fraction of the production costs in all seven scenarios. The obtained annual production costs vary from 2.6 to 4.1 million euros, being 3.4 million euros in the base scenario.

Table 9. Annual production costs (in $k €$ ), variable and fixed, determined for each scenario.

\begin{tabular}{|c|c|c|c|c|c|c|c|}
\hline Production Costs & Sc 1 & Sc 2 & Sc 3 & Sc 4 & Sc 5 & Sc 6 & Sc 7 \\
\hline \multicolumn{8}{|l|}{ Variable costs } \\
\hline Raw materials & 0 & 0 & 0 & 0 & 0 & 0 & 0 \\
\hline Miscellaneous materials & 97 & 90 & 106 & 97 & 97 & 97 & 97 \\
\hline Utilities & 1221 & 721 & 1721 & 1221 & 1221 & 1221 & 1221 \\
\hline Flocculant $(\mathrm{NaOH})$ & 17 & 9 & 26 & 17 & 17 & 17 & 17 \\
\hline Nitrogen source $\left(\mathrm{NH}_{4} \mathrm{NO}_{3}\right)$ & 227 & 113 & 340 & 227 & 227 & 227 & 227 \\
\hline Shipping and packaging & 0 & 0 & 0 & 0 & 0 & 0 & 0 \\
\hline \multicolumn{8}{|l|}{ Fixed costs } \\
\hline Maintenance & 971 & 900 & 1060 & 971 & 971 & 971 & 971 \\
\hline Operating labor & 32 & 32 & 32 & 32 & 32 & 32 & 32 \\
\hline Laboratory costs & 6 & 6 & 6 & 6 & 6 & 6 & 6 \\
\hline Supervision & 6 & 6 & 6 & 6 & 6 & 6 & 6 \\
\hline Plant overheads & 16 & 16 & 16 & 16 & 16 & 16 & 16 \\
\hline Insurance & 194 & 180 & 212 & 194 & 194 & 194 & 194 \\
\hline Local taxes & 389 & 360 & 424 & 389 & 389 & 389 & 389 \\
\hline Royalties & 194 & 180 & 212 & 194 & 194 & 194 & 194 \\
\hline Total $(k €)$ & 3372 & 2615 & 4163 & 3372 & 3372 & 3372 & 3372 \\
\hline
\end{tabular}


Regarding the biorefinery revenues, the main aim of this facility is to treat the industrial effluent and produce lipids and energy. However, other profits were considered, as mentioned in Section 2.2.6. Figure 5 shows the results obtained for each scenario. The industrial effluent treatment, the sale from the accumulated lipids, and the sale of biofertilizers represent the products/services that generate the most profit to the biorefinery in almost all scenarios. Scenario 2 is an exception, with the sludge treatment representing the largest revenue. That is because the same digester volume was assumed for all scenarios. In Scenario 2, the anaerobic reactor has more free space to receive sludge from other sources, which results in a higher profit resulting from sludge treatment. $\mathrm{CO}_{2}$ capture represents the profit with the least impact in the annual revenues of the facility in all scenarios. Although Scenario 3 has the highest value of total annual revenues, and Scenario 2 the lowest, only small variations in the revenues generated between Scenarios 1, 4, 5, 6, and 7 were observed, which result from the different values of the AD or PEF unit efficiency assumed.

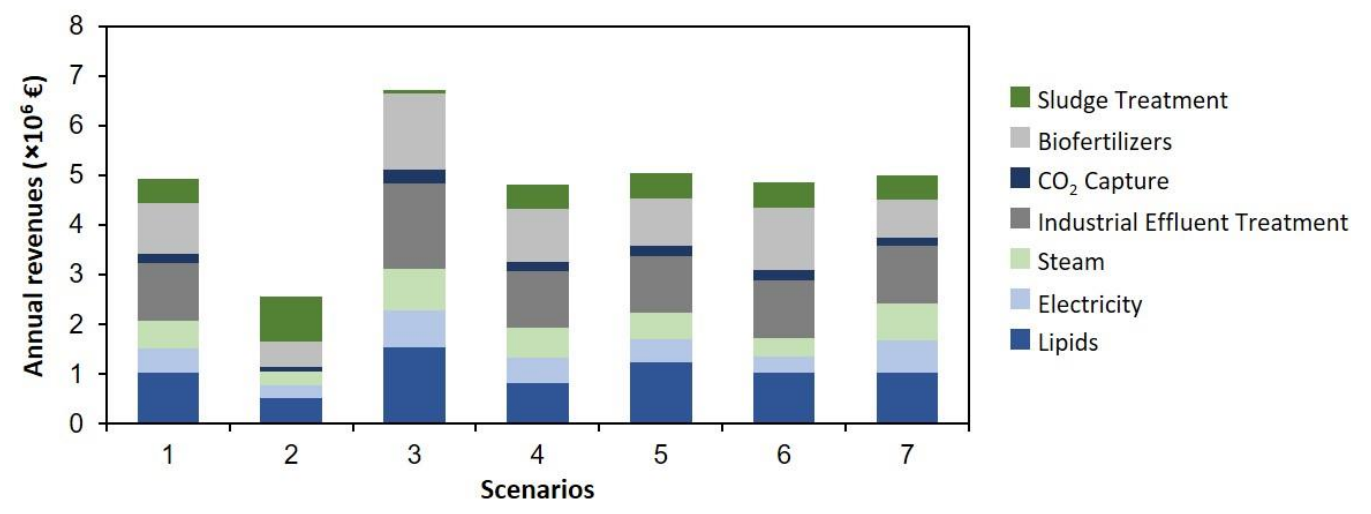

Figure 5. Graphical representation of the annual revenues in each scenario.

Regarding the viability analysis, the values assumed for the different financial variables are summarized in Table 10, and the results of this analysis are presented in Table 11. From the seven studied scenarios, six are economically viable. Only Scenario 2 presents a negative NPV ( -7.4 million euros). On the other hand, Scenario 3 shows the highest NPV, with a relative increase of $203 \%$ compared to the base scenario. Regarding the DPP results, Scenario 3 is the one in which the project is paid in a shorter period (13 years) and, in contrast, in Scenario 2, the biorefinery is not even paid over the project lifetime ( $>30$ years). From the other five scenarios, Scenario 4 is the one that presented the worst estimate for the time needed to pay the initial investment ( 27 years). These results were expected, as it was also in this scenario that the lowest value of annual revenues was recorded. On the other hand, Scenario 5 showed the best result, being paid three years earlier than the project defined in the base scenario. Nevertheless, although the NPV was positive in six scenarios, the time necessary to pay the project can be considered too long. Even in the best scenario, it would take 13 years for the project to start making profit, which, from an investor's point of view, can make the project less appealing and riskier. With regard to IRR value, the project is feasible if the IRR is higher than the defined cost of capital, meaning that the annual revenues are enough to pay the investment capital and the required return. Taking this into consideration, only Scenario 2 showed an IRR value lower than the cost of capital (3\%). Scenario 3 presented the highest IRR, being twice the cost of capital (12\%).

To study the influence that each of the three variables evaluated in the different scenarios has on the NPV, a sensitivity analysis was performed, and the results are shown in Figure 6. PE is the variable that has the greatest impact on the project NPV, ranging between -7.4 and 19.5 million euros, for PEs of 1 and 3\%, respectively. Concerning the other two variables, lipids extraction efficiency has a slightly greater influence on the economic viability of the project than the anaerobic digestion efficiency. Indeed, a greater oscillation in the NPV was observed in the scenarios assuming a PEF unit efficiency of 60, 
75, or 90\%: 4.7-8.2 million euros. On the other hand, for anaerobic digestion efficiencies between 30 and $60 \%$, the NPV varies from 5.3 to 7.5 million euros.

Table 10. Financial parameters assumed in the economic viability assessment.

\begin{tabular}{cc}
\hline Parameter & Assumed Value \\
\hline VAT (\%) & 10 \\
CIT (\%) & 21 \\
Inflation (\%) & 1.5 \\
Cost of capital (\%) & 6 \\
Working capital needs (\%) & 5 \\
Project lifetime period (yr) & 30 \\
\hline
\end{tabular}

VAT-value-added tax; CIT-corporate income tax.

Table 11. Economic viability results determined for each scenario.

\begin{tabular}{cccccccc}
\hline Parameter & Sc $\mathbf{1}$ & Sc $\mathbf{2}$ & Sc $\mathbf{3}$ & Sc $\mathbf{4}$ & Sc 5 & Sc 6 & Sc 7 \\
\hline NPV $(\mathrm{k} €)$ & 5070 & -7411 & 15,375 & 3699 & 6440 & 4210 & 5929 \\
IRR $(\%)$ & 8 & 3 & 12 & 8 & 9 & 8 & 9 \\
PP (yr) & 13 & 29 & 9 & 14 & 12 & 13 & 12 \\
DPP (yr) & 23 & $>30$ & 13 & 27 & 20 & 25 & 21 \\
\hline
\end{tabular}

NPV—net present value; IRR—internal rate of return; PP—payback period; DPP—discounted payback period.

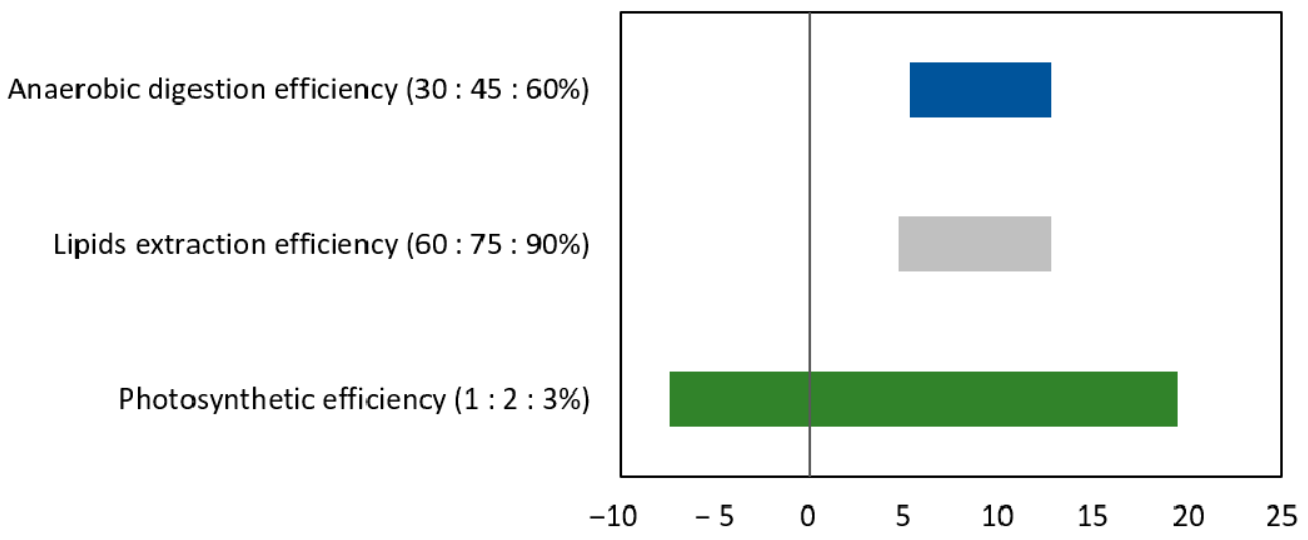

Figure 6. Sensitivity analysis of the proposed biorefinery, considering the variables changed between the studied scenarios.

Improved economic indicators were obtained in a similar study performed by Gonçalves et al. [25]. In this study, aiming at evaluating the economic viability of bioenergy production from microalgae using municipal wastewaters as culture medium, the authors obtained the following results: (i) a NPV ranging between -12.1 and 22.6 million euros; (ii) a PP of 4 to 8 years; and (iii) an IRR ranging between 13 and $26 \%$. The authors also concluded that the scenario assuming the lowest PE was not economically viable. The highest performance of this microalgal facility when compared to the one proposed in the present study may be a result of different factors: (i) the effluent to be treated in the present study required an external nitrogen source, which increases the operational costs; (ii) although the same equipment was assumed in the acquisition costs, it was defined that the dimensioned equipment corresponded only to $85 \%$ of the total acquisition costs instead of the $90 \%$ assumed in the reference study; (iii) the values assumed for equipment acquisition costs and financial parameters were adjusted to the current reality of the country. Other studies from the literature have also demonstrated the economic viability of microalgal production for different applications. Thomassen et al. [79] performed an environmental TEA for several value chains using microalgal biorefineries as a model. In this study, the authors concluded that the optimal value chains included as main processes: open pond 
cultivation and medium recycling, as in the microalgal biorefinery proposed in the present study, and spray drying (a step that was avoided in this study because the PEF technology used for lipids extraction can be applied to wet biomass). Comparing different value chains, the authors concluded that the most economic was the one using Nannochloropsis sp. for the production of fish larvae feed, presenting a NPV of 180 million euros. The authors also evaluated two value chains intended for bioenergy production through anaerobic digestion, obtaining a NPV of 17.1 and 154 million euros for Dunaliella salina and Haematococcus pluvialis, respectively. Similarly, Ahmad Ansari et al. [80] evaluated the economic feasibility of using the microalga Scenedesmus obliquus in aquaculture. In this study, the authors evaluated two scenarios: in scenario 1 , microalgal biomass was directly used for fish production, and in scenario 2, microalgal biomass was firstly used for lipids extraction and biodiesel production and the residual biomass was applied in fishmeal diets. With this study, the authors concluded that the use of microalgal biomass for the dual purpose of biodiesel production and fishmeal formulations was more profitable than the single use of microalgal biomass for fish production: (i) the net profit determined in scenarios 1 and 2 was 426 and 531 thousand euros per year, respectively; and (ii) the PP determined for scenario 1 was 7.5 years, whereas the PP determined for scenario 2 was 6.8 years. These results confirm the advantages of exploring several products/applications of microalgal biomass within the biorefinery approach, as it was proposed in the present study.

\subsubsection{Sustainability Assessment}

The results of the two analyzed sustainability parameters are shown in Table 12. An analysis of the net $\mathrm{CO}_{2}$ balance demonstrated that this parameter was negative in all the studied scenarios, meaning that there is more consumption of $\mathrm{CO}_{2}$ by microalgae than that released in the biorefinery processes. The scenario with the highest PE, Scenario 3, has higher biomass productivity and, therefore, requires more $\mathrm{CO}_{2}$, resulting in a higher value of the net $\mathrm{CO}_{2}$ balance in absolute terms.

Table 12. Net $\mathrm{CO}_{2}$ balance and energy returned on energy invested results for each scenario.

\begin{tabular}{|c|c|c|c|c|c|c|c|}
\hline Parameter & Sc 1 & Sc 2 & Sc 3 & Sc 4 & Sc 5 & Sc 6 & Sc 7 \\
\hline \multicolumn{8}{|l|}{$\mathrm{CO}_{2}$ balance } \\
\hline $\mathrm{CO}_{2}$ required in the cultivation step $\left(\mathrm{t} \mathrm{d}^{-1}\right)$ & 31 & 16 & 47 & 31 & 31 & 31 & 31 \\
\hline $\mathrm{CO}_{2}$ resulting from $\mathrm{CHP}$ generation $\left(\mathrm{t} \mathrm{d}^{-1}\right)$ & 7.9 & 4.0 & 11.9 & 8.3 & 7.6 & 5.3 & 10.6 \\
\hline Net $\mathrm{CO}_{2}$ balance $\left(\mathrm{t} \mathrm{d}^{-1}\right)$ & -17 & -8.5 & -26 & -17 & -17 & -20 & -14 \\
\hline \multicolumn{8}{|l|}{ Energy balance } \\
\hline Energy produced in the CHP unit $\left(\times 10^{4} \mathrm{kWh}^{-1}\right)$ & 2.1 & 1.0 & 3.1 & 2.2 & 2.0 & 1.4 & 2.8 \\
\hline $\begin{array}{l}\text { Total energy produced from the biorefineries } \\
\text { exploited products }\left(\times 10^{4} \mathrm{kWh} \mathrm{d}^{-1}\right)\end{array}$ & 5.0 & 2.5 & 7.6 & 4.6 & 5.6 & 4.3 & 5.8 \\
\hline Energy consumed $\left(\times 10^{4} \mathrm{kWh} \mathrm{d}^{-1}\right)$ & 2.4 & 1.4 & 3.3 & 2.4 & 2.4 & 2.4 & 2.4 \\
\hline EROEI (from the CHP unit) & 0.87 & 0.73 & 0.92 & 0.91 & 0.83 & 0.58 & 1.2 \\
\hline EROEI (from the CHP unit and extracted lipids) & 2.1 & 1.8 & 2.3 & 1.9 & 2.3 & 1.8 & 2.5 \\
\hline
\end{tabular}

CHP—combined heat and power; EROEI—energy returned on energy invested.

Concerning the EROEI results, they can be analyzed in two different ways: (i) considering only the energy produced in the biorefinery; and (ii) considering the energy that is produced in the industrial plant, as well as the energy that can be obtained from the main exploited product, lipids. Looking at the first case results, the value of this parameter is lower than 1 in all scenarios, except for Scenario 7, due to the higher efficiency of the anaerobic digestion assumed $(60 \%)$. Therefore, the proposed project would only be energetically efficient in one of the studied scenarios, promoting a self-sustained biorefinery. In the other scenarios, it would be necessary to buy energy from the network to fulfill the energy needs of the plant. In the worst scenario, Scenario 6, where a low efficiency of the AD was assumed $(30 \%)$, approximately $10,000 \mathrm{kWh}$ from the energy network would be required per day. Regarding the second case, EROEI was higher than 1 in all studied scenarios. 
These results demonstrate that this biorefinery can promote clean energy production in greater quantities than what it consumes, even in Scenario 2, which always presented the worst results in the other assessments. Scenario 7, with an EROEI of 2.5, demonstrated the best capacity to promote energy production. The reason why the results of this second case are not so accurate is that the energy obtained from the extracted lipids is being accounted for, but the energy consumed outside the biorefinery boundaries in the transesterification of lipids into biodiesel is not.

In addition to these parameters, from a sustainability point of view, it is also important to highlight other benefits of this project that may be intangible and/or unmeasurable, but add value to it: (i) reduction of GHGs emissions and mitigation of the effects of climate change; (ii) contribution to a circular economy, with the production of biofertilizers from sludge (which returns nutrients to the soil), and with the use of wastewater as a culture medium; (iii) soils' regeneration; (iv) contribution to mitigate environmental issues, such as eutrophication; (v) creation of new jobs, with reasonable salary conditions; and (vi) promotion of seven of the United Nations Sustainable Development Goals (SDGs).

This project can benefit from the current and future policies from the paper industry company. There is a commitment that all units should be neutral in carbon emissions by 2035 and an investment of more than $100 \mathrm{M} €$ was estimated. Moreover, the implementation of this biological process will enable to reduce the requirements of freshwater for the processes, enabling the possibility of wastewater reuse after treatment. The production of fertilizers with lower environmental impact from wastewater can also benefit from national and European policies from nutrient recycling.

\section{Conclusions}

This work was divided into two parts: (i) a laboratory step to evaluate the growth behavior of the microalga $C$. vulgaris in a paper industry effluent and its ability to remove phosphorus from this culture medium, and (ii) a techno-economic analysis to design a microalgal-based remediation and bioenergy production plant. The study demonstrated that the paper industry effluent did not have an inhibitory effect on $C$. vulgaris growth and showed the feasibility of using this microalga for phosphorus removal from paper industry effluents. Phosphorus final concentrations determined on each assay ranged between $0.12 \pm 0.01$ and $0.5 \pm 0.3 \mathrm{mg} \mathrm{P} \mathrm{L}^{-1}$, being below the legal limits imposed by APA for this industry.

Concerning the TEA results, this paper presents an economically viable microalgalbased biorefinery for industrial effluent treatment and bioenergy production, with a NPV of 15.4 million euros and a $12 \%$ IRR in the best studied scenario. In this scenario, a $3 \%$ $\mathrm{PE}$, a PEF extraction efficiency of $75 \%$, and an anaerobic digestion efficiency of $45 \%$ were considered. When analyzing the DPP values, the best scenario presents a DPP of 13 years, which can make the project less appealing for possible stakeholders. Nevertheless, this project presents several benefits, especially at the sustainability level: (i) a reduction in GHGs emissions; (ii) the treatment of an effluent that is commonly associated with the eutrophication phenomenon (due to its phosphorus concentration); (iii) the possibility of nutrients' recycling and soils' regeneration; (iv) the production of carbon-neutral biofuels; and (v) the development of a circular economy.

Supplementary Materials: The following are available online at https:/ / www.mdpi.com/2071-105 0/13/3/1314/s1, Table S1: Fractions of the total equipment purchase cost assumed to determine the direct and indirect costs of the investment capital and values assumed for the determination of variable and fixed production costs.

Author Contributions: Conceptualization, A.L.G. and J.C.M.P.; methodology, M.I.S. and A.L.G.; investigation, M.I.S., A.L.G., and J.C.M.P.; resources, V.J.P.V. and J.C.M.P.; data curation, M.I.S., A.L.G., and J.C.M.P.; writing—original draft preparation, M.I.S.; writing—review and editing, M.I.S., A.L.G., V.J.P.V., and J.C.M.P.; supervision, A.L.G., V.J.P.V., and J.C.M.P.; project administration, V.J.P.V. and J.C.M.P.; funding acquisition, V.J.P.V. and J.C.M.P. All authors have read and agreed to the published version of the manuscript. 
Funding: This work was financially supported by: (i) Base Funding-UIDB/00511/2020 of the Laboratory for Process Engineering, Environment, Biotechnology and Energy_LEPABE—funded by national funds through the FCT/MCTES (PIDDAC); (ii) Base Funding-UIDB/50020/2020 of the Associate Laboratory LSRE-LCM—funded by national funds through FCT/MCTES (PIDDAC); and (iii) Project PTDC/BTA-BTA/31736/2017-POCI-01- 0145-FEDER-031736—funded by FEDER funds through COMPETE2020—Programa Operacional Competitividade e Internacionalização (POCI) and with the financial support of FCT/MCTES through national funds (PIDDAC). V.J.P. Vilar acknowledges the FCT Individual Call to Scientific Employment Stimulus 2017 (CEECIND/01317/2017). J.C.M. Pires acknowledges the FCT Investigator 2015 Programme (IF/01341/2015).

Institutional Review Board Statement: Not applicable.

Informed Consent Statement: Not applicable.

Data Availability Statement: The data presented in this study are available in the article and in the supplementary material.

Conflicts of Interest: The authors declare no conflict of interest.

\section{Abbreviations}

\begin{tabular}{ll} 
Acronyms & \\
AD & Anaerobic digester \\
APA & Agência Portuguesa do Ambiente-Portuguese Environment Agency \\
CCAP & Culture Collection of Algae and Protozoa \\
CEPCI & Chemical Engineering Plant Cost Index \\
CHP & Combined heat and power \\
CIT & Corporate income tax \\
COD & Chemical oxygen demand \\
DPP & Discounted payback period \\
DW & Dry weight \\
EROEI & Energy returned on energy invested \\
GHG & Greenhouse gas \\
HRP & High rate pond \\
IRR & Internal rate of return \\
LED & Light-emitting diode \\
NPV & Net present value \\
OD & Optical density \\
OECD & Organization for Economic Co-operation and Development \\
PAR & Photosynthetically-active radiation \\
PE & Photosynthetic efficiency \\
PEF & Pulsed electric field \\
PP & Payback period \\
PVGIS & Photovoltaic geographical information system \\
rpm & Rotations per minute \\
SDG & Sustainable development goals \\
TEA & Techno-economic assessment \\
USEPA & United States Environmental Protection Agency \\
VAT & Value-added tax \\
WWTP & Wastewater treatment plant \\
& \\
\hline
\end{tabular}




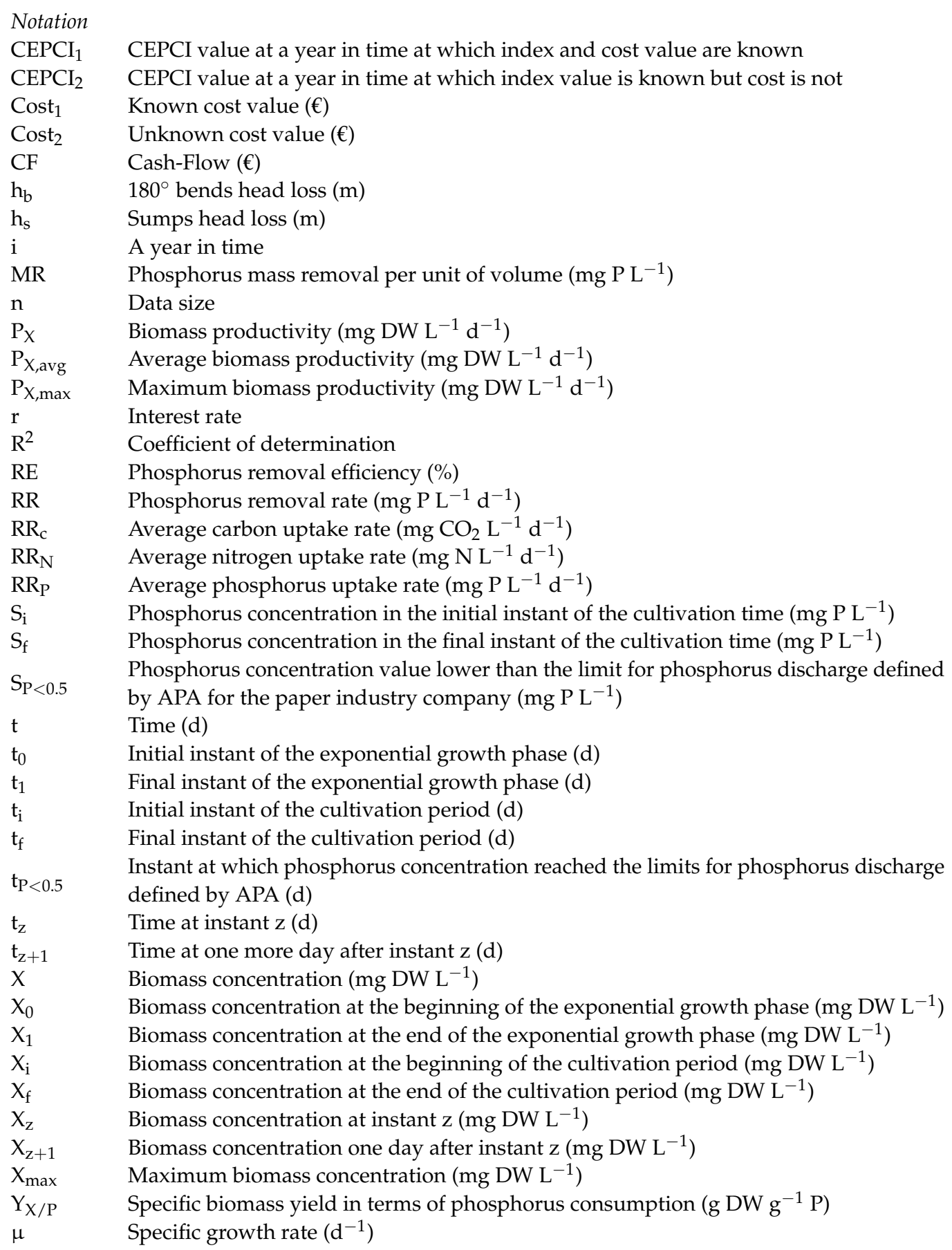

\section{References}

1. Koyande, A.K.; Show, P.-L.; Guo, R.; Tang, B.; Ogino, C.; Chang, J.-S. Bio-processing of algal bio-refinery: A review on current advances and future perspectives. Bioengineered 2019, 10, 574-592. [CrossRef] [PubMed]

2. Owusu, P.A.; Asumadu-Sarkodie, S. A review of renewable energy sources, sustainability issues and climate change mitigation. Cogent Eng. 2016, 3, 1167990. [CrossRef]

3. Mata, T.M.; Martins, A.A.; Caetano, N.S. Microalgae for biodiesel production and other applications: A review. Renew. Sustain. Energy Rev. 2010, 14, 217-232. [CrossRef]

4. USEPA. Global Greenhouse Gas Emissions Data. Available online: https://www.epa.gov/ghgemissions/global-greenhouse-gasemissions-data (accessed on 22 May 2020).

5. Aydın, M.; Uslu, S.; Bahattin Çelik, M. Performance and emission prediction of a compression ignition engine fueled with biodiesel-diesel blends: A combined application of ANN and RSM based optimization. Fuel 2020, 269, 117472-117481. [CrossRef]

6. Demirbas, M.F. Biofuels from algae for sustainable development. Appl. Energy 2011, 88, 3473-3480. [CrossRef] 
7. Ribeiro, L.A.; Silva, P.P. Technoeconomic assessment on innovative biofuel technologies: The case of microalgae. ISRN Renew. Energy 2012, 2012, 1-8. [CrossRef]

8. Venkata Mohan, S.; Hemalatha, M.; Chakraborty, D.; Chatterjee, S.; Ranadheer, P.; Kona, R. Algal biorefinery models with self-sustainable closed loop approach: Trends and prospective for blue-bioeconomy. Bioresour. Technol. 2020, 295, 122128-122140. [CrossRef]

9. Simsek, S.; Uslu, S. Comparative evaluation of the influence of waste vegetable oil and waste animal oil-based biodiesel on diesel engine performance and emissions. Fuel 2020, 280, 118613-118619. [CrossRef]

10. Venu, H.; Subramani, L.; Raju, V.D. Emission reduction in a DI diesel engine using exhaust gas recirculation (EGR) of palm biodiesel blended with $\mathrm{TiO}_{2}$ nano additives. Renew. Energy 2019, 140, 245-263. [CrossRef]

11. Scaldaferri, C.A.; Pasa, V.M.D. Production of jet fuel and green diesel range biohydrocarbons by hydroprocessing of soybean oil over niobium phosphate catalyst. Fuel 2019, 245, 458-466. [CrossRef]

12. Lardon, L.; Hélias, A.; Sialve, B.; Steyer, J.-P.; Bernard, O. Life-cycle assessment of biodiesel production from microalgae. Environ. Sci. Technol. 2009, 43, 6475-6481. [CrossRef] [PubMed]

13. Pugliese, A.; Biondi, L.; Bartocci, P.; Fantozzi, F. Selenastrum capricornutum a new strain of algae for biodiesel production. Fermentation 2020, 6, 46. [CrossRef]

14. Viccaro, M.; Cozzi, M.; Rocchi, B.; Romano, S. Conservation agriculture to promote inland biofuel production in Italy: An economic assessment of rapeseed straight vegetable oil as a self-supply agricultural biofuel. J. Clean. Prod. 2019, 217, 153-161. [CrossRef]

15. Chisti, Y. Biodiesel from microalgae beats bioethanol. Trends Biotechnol. 2008, 26, 126-131. [CrossRef] [PubMed]

16. Dillschneider, R.; Steinweg, C.; Rosello-Sastre, R.; Posten, C. Biofuels from microalgae: Photoconversion efficiency during lipid accumulation. Bioresour. Technol. 2013, 142, 647-654. [CrossRef]

17. Liang, Y.; Kashdan, T.; Sterner, C.; Dombrowski, L.; Petrick, I.; Kröger, M.; Höfer, R. Algal biorefineries. In Industrial Biorefineries $\mathcal{E}$ White Biotechnology; Pandey, A., Höfer, R., Taherzadeh, M., Nampoothiri, K.M., Larroche, C., Eds.; Elsevier: Amsterdam, The Netherlands, 2015; pp. 35-90. [CrossRef]

18. Rawat, I.; Ranjith Kumar, R.; Mutanda, T.; Bux, F. Dual role of microalgae: Phycoremediation of domestic wastewater and biomass production for sustainable biofuels production. Appl. Energy 2011, 88, 3411-3424. [CrossRef]

19. Dias, M.; Cavalett, O.; Maciel Filho, R.; Bonomi, A. Integrated first and second generation ethanol production from sugarcane. Chemical Eng. Trans. 2014, 37, 445-450. [CrossRef]

20. OECD. Freshwater alga and cyanobacteria, growth inhibition test. In Test Guideline 201; Organisation for Economic Co-operation and Development: Paris, France, 2011.

21. APHA. Standard Methods for the Examination of Water and Wastewater, 20th ed.; American Public Health Association: Washington DC, USA, 1999.

22. USEPA. Method 352.1: Nitrogen, Nitrate (Colorimetric, Brucine) by Spectrophotometer; USEPA: Washington, DC, USA, 1971.

23. Larsdotter, K. Wastewater treatment with microalgae: A literature review. Vatten 2006, 62, 31-38.

24. Daliry, S.; Hallajisani, A.; Roshandeh, J.M.; Nouri, H.; Golzary, A. Investigation of optimal condition for Chlorella vulgaris microalgae growth. Glob. J. Environ. Sci. Manag. 2017, 3, 217-230. [CrossRef]

25. Gonçalves, A.L.; Alvim-Ferraz, M.C.M.; Martins, F.G.; Simões, M.; Pires, J.C.M. Integration of microalgae-based bioenergy production into a petrochemical complex: Techno-economic assessment. Energies 2016, 9, 224. [CrossRef]

26. Rodrigues, C.M.M. Cálculo da Evaporação de Albufeiras de Grande Regularização do sul de Portugal. Ph.D. Thesis, Universidade de Évora, Évora, Portugal, 2009.

27. Gifuni, I.; Pollio, A.; Safi, C.; Marzocchella, A.; Olivieri, G. Current bottlenecks and challenges of the microalgal biorefinery. Trends Biotechnol. 2019, 37, 242-252. [CrossRef] [PubMed]

28. Kang, S.; Heo, S.; Lee, J.H. Techno-economic analysis of microalgae-based lipid production: Considering influences of microalgal species. Ind. Eng. Chem. Res. 2019, 58, 944-955. [CrossRef]

29. Barros, A.I.; Gonçalves, A.L.; Simões, M.; Pires, J.C.M. Harvesting techniques applied to microalgae: A review. Renew. Sustain. Energy Rev. 2015, 41, 1489-1500. [CrossRef]

30. Brennan, L.; Owende, P. Biofuels from microalgae: A review of technologies for production, processing, and extractions of biofuels and co-products. Renew. Sustain. Energy Rev. 2010, 14, 557-577. [CrossRef]

31. Buchmann, L.; Mathys, A. Perspective on pulsed electric field treatment in the bio-based industry. Front. Bioeng. Biotechnol. 2019, 7, 265-271. [CrossRef] [PubMed]

32. Eing, C.; Goettel, M.; Straessner, R.; Gusbeth, C.; Frey, W. Pulsed electric field treatment of microalgae: Benefits for microalgae biomass processing. IEEE Trans. Plasma Sci. 2013, 41, 2901-2907. [CrossRef]

33. Joannes, C.; Sipaut, C.S.; Dayou, J.; Yasir, S.M.; Mansa, R.F. The potential of using pulsed electric field (PEF) technology as the cell disruption method to extract lipid from microalgae for biodiesel production. Int. J. Renew. Energy Res. 2015, 5, 598-621.

34. Leonhardt, L.; Käferböck, A.; Smetana, S.; de Vos, R.; Toepfl, S.; Parniakov, O. Bio-refinery of Chlorella sorokiniana with pulsed electric field pre-treatment. Bioresour. Technol. 2020, 301, 122743-122750. [CrossRef]

35. Carvalho, A.P.; Meireles, L.A.; Malcata, F.X. Microalgal reactors: A review of enclosed system designs and performances. Biotechnol. Prog. 2006, 22, 1490-1506. [CrossRef] 
36. de Vree, J.H.; Bosma, R.; Janssen, M.; Barbosa, M.J.; Wijffels, R.H. Comparison of four outdoor pilot-scale photobioreactors. Biotechnol. Biofuels 2015, 8, 215-226. [CrossRef]

37. Williams, P.J.1.B.; Laurens, L.M. Microalgae as biodiesel \& biomass feedstocks: Review \& analysis of the biochemistry, energetics \& economics. Energy Environ. Sci. 2010, 3, 554-590. [CrossRef]

38. Joannes, C.; Sipaut, C.S.; Dayou, J.; Yasir, S.M.; Mansa, R.F. Review paper on cell membrane electroporation of microalgae using electric field treatment method for microalgae lipid extraction. In Proceedings of the 9th CUTSE International Conference, Miri, Sarawak, Malaysia, 3-4 December 2014.

39. Zbinden, M.D.; Sturm, B.S.; Nord, R.D.; Carey, W.J.; Moore, D.; Shinogle, H.; Stagg-Williams, S.M. Pulsed electric field (PEF) as an intensification pretreatment for greener solvent lipid extraction from microalgae. Biotechnol. Bioeng. 2013, 110, 1605-1615. [CrossRef]

40. Kinnunen, V.; Craggs, R.; Rintala, J. Influence of temperature and pretreatments on the anaerobic digestion of wastewater grown microalgae in a laboratory-scale accumulating-volume reactor. Water Res. 2014, 57, 247-257. [CrossRef] [PubMed]

41. Lundquist, T.J.; Woertz, I.C.; Quinn, N.; Benemann, J.R. A Realistic Technology and Engineering assessment of Algae Biofuel Production; Energy Biosciences Institute: Berkeley, CA, USA, 2010.

42. Chen, Z.; Wang, L.; Shuang Qiu, S.G. Determination of microalgal lipid content and fatty acid for biofuel production. BioMed Res. Int. 2018, 2018, 1503126. [CrossRef] [PubMed]

43. Dong, T.; Knoshaug, E.P.; Pienkos, P.T.; Laurens, L.M.L. Lipid recovery from wet oleaginous microbial biomass for biofuel production: A critical review. Appl. Energy 2016, 177, 879-895. [CrossRef]

44. Tran, K.C.; Mendoza Martin, J.L.; Heaven, S.; Banks, C.J.; Acien Fernandez, F.G.; Molina Grima, E. Cultivation and anaerobic digestion of Scenedesmus spp. grown in a pilot-scale open raceway. Algal Res. 2014, 5, 95-102. [CrossRef]

45. Acién, F.G.; Molina, E.; Reis, A.; Torzillo, G.; Zittelli, G.C.; Sepúlveda, C.; Masojídek, J. Photobioreactors for the production of microalgae. In Microalgae-Based Biofuels and Bioproducts; Gonzalez-Fernandez, C., Muñoz, R., Eds.; Woodhead Publishing: Sawston, UK, 2017; pp. 1-44. [CrossRef]

46. Gonçalves, A.L.; Rodrigues, C.M.; Pires, J.C.M.; Simões, M. The effect of increasing $\mathrm{CO}_{2}$ concentrations on its capture, biomass production and wastewater bioremediation by microalgae and cyanobacteria. Algal Res. 2016, 14, 127-136. [CrossRef]

47. Porto, B.; Gonçalves, A.L.; Esteves, A.F.; Ulson de Souza, S.M.A.G.; Ulson de Souza, A.A.; Vilar, V.J.P.; Pires, J.C.M. Microalgal growth in paper industry effluent: Coupling biomass production with nutrients removal. Appl. Sci. 2020, 10, 3009. [CrossRef]

48. Vandamme, D. Flocculation Based Harvesting Processes for Microalgae Biomass Production. Ph.D. Thesis, Faculty of Bioscience Engineering, KU Leuven, Leuven, Belgium, 2013.

49. Fasaei, F.; Bitter, J.H.; Slegers, P.M.; van Boxtel, A.J.B. Techno-economic evaluation of microalgae harvesting and dewatering systems. Algal Res. 2018, 31, 347-362. [CrossRef]

50. Najjar, Y.S.H.; Abu-Shamleh, A. Harvesting of microalgae by centrifugation for biodiesel production: A review. Algal Res. 2020, 51, 102046-102061. [CrossRef]

51. Jankowska, E.; Sahu, A.K.; Oleskowicz-Popiel, P. Biogas from microalgae: Review on microalgae's cultivation, harvesting and pretreatment for anaerobic digestion. Renew. Sustain. Energy Rev. 2017, 75, 692-709. [CrossRef]

52. Klassen, V.; Blifernez-Klassen, O.; Wibberg, D.; Winkler, A.; Kalinowski, J.; Posten, C.; Kruse, O. Highly efficient methane generation from untreated microalgae biomass. Biotechnol. Biofuels 2017, 10, 186-197. [CrossRef] [PubMed]

53. Milledge, J.J.; Nielsen, B.V.; Maneein, S.; Harvey, P.J. A brief review of anaerobic digestion of algae for bioenergy. Energies 2019, 12, 1166. [CrossRef]

54. Kudela, H. Hydraulic Losses in Pipes; Wrocław University of Science and Technology: Wrocław, Poland, 2012.

55. Li, Y.; Zhang, Q.; Wang, Z.; Wu, X.; Cong, W. Evaluation of power consumption of paddle wheel in an open raceway pond. Bioprocess Biosyst. Eng. 2014, 37, 1325-1336. [CrossRef] [PubMed]

56. Vitázek, I.; Klúčik, J.; Mikulová, Z.; Vereš, P. Effects on concentration of selected gaseous emissions at biomass combustion. AIP Conf. Proc. 2016, 1768, 020022-020032. [CrossRef]

57. UNEP. Energy Efficiency Guide for Industria in Asia: Electrical Energy Equipment (Fans and Blowers); UNEP: Nairobi, Kenya, 2006.

58. Milledge, J.J.; Heaven, S. Disc stack centrifugation separation and cell disruption of microalgae: A technical note. Environ. Nat. Resour. Res. 2011, 1, 17-24. [CrossRef]

59. Flisar, K.; Meglic, S.H.; Morelj, J.; Golob, J.; Miklavcic, D. Testing a prototype pulse generator for a continuous flow system and its use for E. coli inactivation and microalgae lipid extraction. Bioelectrochemistry 2014, 100, 44-51. [CrossRef]

60. SGC. Basic Data on Biogas; SGC: Malmö, Sweden, 2012.

61. Pöschl, M.; Ward, S.; Owende, P. Evaluation of energy efficiency of various biogas production and utilization pathways. Appl. Energy 2010, 87, 3305-3321. [CrossRef]

62. Fux, C.; Siegrist, H. Nitrogen removal from sludge digester liquids by nitrification/denitrification or partial nitritation/anammox: Environmental and economical considerations. Water Sci. Technol. 2004, 50, 19-26. [CrossRef]

63. PORDATA. Preços da Eletrecidade para Utilizadores Domésticos e Industriais (Euro/ECU). Available online: https: / / www.pordata.pt/Europa/Pre\%c3\%a7os+da+electricidade+para+utilizadores+dom\%c3\%a9sticos+e+industriais+(Euro+ ECU)-1477-313029 (accessed on 20 July 2020).

64. Zamalloa, C.; Vulsteke, E.; Albrecht, J.; Verstraete, W. The techno-economic potential of renewable energy through the anaerobic digestion of microalgae. Bioresour. Technol. 2011, 102, 1149-1158. [CrossRef] 
65. Acién, F.G.; Fernández, J.M.; Magán, J.J.; Molina, E. Production cost of a real microalgae production plant and strategies to reduce it. Biotechnol. Adv. 2012, 30, 1344-1353. [CrossRef] [PubMed]

66. Declercq, B.; Delarue, E.; D'haeseleer, W. Impact of the economic recession on the European power sector's $\mathrm{CO}_{2} \mathrm{emissions}$ Energy Policy 2011, 39, 1677-1686. [CrossRef]

67. PORDATA. Taxa de Inflação (Taxa de Variação do Índice de Preços no Consumidor): Total e por Consumo Individual por Objetivo. Available online: https:/ / www.pordata.pt/DB/Portugal/Ambiente+de+Consulta/Tabela (accessed on 2 August 2020).

68. Areias, R.; Figueiredo, J.; Verschoor, L. Corporate: Taxes on Corporate Income. Available online: https://taxsummaries.pwc. $\mathrm{com} /$ portugal/corporate/taxes-on-corporate-income (accessed on 2 August 2020).

69. Damodaran, A. Cost of Capital by Sector (US). Available online: http://people.stern.nyu.edu/adamodar/New_Home_Page/ datafile/wacc.htm (accessed on 2 August 2020).

70. Hoffman, J.; Pate, R.C.; Drennen, T.; Quinn, J.C. Techno-economic assessment of open microalgae production systems. Algal Res. 2017, 23, 51-57. [CrossRef]

71. Sayre, R. Microalgae: The potential for carbon capture. BioScience 2010, 60, 722-727. [CrossRef]

72. Tao, R.; Kinnunen, V.; Praveenkumar, R.; Lakaniemi, A.-M.; Rintala, J.A. Comparison of Scenedesmus acuminatus and Chlorella vulgaris cultivation in liquid digestates from anaerobic digestion of pulp and paper industry and municipal wastewater treatment sludge. J. Appl. Phycol. 2017, 29, 2845-2856. [CrossRef]

73. Chu, W.L.; Phang, S.M. Biosorption of heavy metals and dyes from industrial effluents by microalgae. In Microalgae Biotechnology for Development of Biofuel and Wastewater Treatment; Alam, M., Wang, Z., Eds.; Springer: Singapore, 2019; pp. 599-634. [CrossRef]

74. Polishchuk, A.; Valev, D.; Tarvainen, M.; Mishra, S.; Kinnunen, V.; Antal, T.; Yang, B.; Rintala, J.; Tyystjärvi, E. Cultivation of Nannochloropsis for eicosapentaenoic acid production in wastewaters of pulp and paper industry. Bioresour. Technol. 2015, 193, 469-476. [CrossRef]

75. Usha, M.T.; Sarat Chandra, T.; Sarada, R.; Chauhan, V.S. Removal of nutrients and organic pollution load from pulp and paper mill effluent by microalgae in outdoor open pond. Bioresour. Technol. 2016, 214, 856-860. [CrossRef]

76. Gentili, F.G. Microalgal biomass and lipid production in mixed municipal, dairy, pulp and paper wastewater together with added flue gases. Bioresour. Technol. 2014, 169, 27-32. [CrossRef]

77. Pereira, S.F.L.; Gonçalves, A.L.; Moreira, F.C.; Silva, T.F.C.V.; Vilar, V.J.P.; Pires, J.C.M. Nitrogen removal from landfill leachate by microalgae. Int. J. Mol. Sci. 2016, 17, 1926. [CrossRef]

78. Silva, N.F.P.; Gonçalves, A.L.; Moreira, F.C.; Silva, T.F.C.V.; Martins, F.G.; Alvim-Ferraz, M.C.M.; Boaventura, R.A.R.; Vilar, V.J.P.; Pires, J.C.M. Towards sustainable microalgal biomass production by phycoremediation of a synthetic wastewater: A kinetic study. Algal Res. 2015, 11, 350-358. [CrossRef]

79. Thomassen, G.; Van Dael, M.; You, F.; Van Passel, S. A multi-objective optimization-extended techno-economic assessment: Exploring the optimal microalgal-based value chain. Green Chem. 2019, 21, 5945-5959. [CrossRef]

80. Ahmad Ansari, F.; Nasr, M.; Guldhe, A.; Kumar Gupta, S.; Rawat, I.; Bux, F. Techno-economic feasibility of algal aquaculture via fish and biodiesel production pathways: A commercial-scale application. Sci. Total Environ. 2020, 704, 135259-135269. [CrossRef] [PubMed] 